\title{
Global patterns of moss diversity: taxonomic and molecular inferences
}

\author{
A. Jonathan Shaw ${ }^{1}$, Cymon J. $\operatorname{Cox}^{1} \&$ Bernard Goffinet $^{2}$ \\ ${ }^{1}$ Department of Biology, Duke University,Durham, North Carolina 27278, U.S.A. shaw@duke.edu (authorfor \\ correspondence); cymon@duke.edu \\ 2 Department of Ecology and Evolution, University of Connecticut, Storrs, Connecticut, 06269, U.S.A. \\ goffinet@uconn.edu
}

Taxonomic and molecular data were utilized to test the hypothesis that moss diversity is greatest near the equator. Species richness estimates from 86 taxonomic checklists representing global moss diversity do not support the hypothesis that, in general, mosses are more species-rich in the tropics than at higher latitudes. A significant latitudinal gradient was, however, detected for North, Central, and South American samples when analyzed alone. Taxonomic estimates of biodiversity patterns were compared to molecular estimates based on standing nucleotide diversity, and on phylogenetic diversity, the latter taking into account the historical information contained in a molecular phylogenetic tree for the mosses. Molecular estimates suggest that moss diversity is highest in the Southern Hemisphere and lowest in the Northern Hemisphere, with the tropics having an intermediate level. The differences, however, are slight, and analyses of molecular variance (AMOVA) indicate that there is virtually no generalized differentiation between major latitudinal zones. These results reflect the fact that virtually all moss lineages have representatives in all three latitudinal zones. At the nucleotide level, mosses best fit the pattern of "everything is everywhere".

KEYWORDS: latitudinal biodiversity gradient, moss phylogeny, nad5 intron, $r p s 4$, phylogenetic diversity, tropical biodiversity.

\section{INTRODUCTION}

A latitudinal gradient of decreasing species diversity from the tropics toward the poles is considered to be one of the few truly general patterns in biogeography and ecology (Rosenzweig, 1995). As a result, a voluminous body of literature has accumulated over the last 30 years, dedicated to explaining the basis of the latitudinal gradient (Rohde, 1992). Substantial progress has been made toward cataloging moss diversity through floristic treatments of many tropical areas. During this effort, bryologists have repeatedly noted that there appear to be high levels of species diversity in the tropics (e.g., Argent, 1979; Gradstein \& Pocs, 1989; Frahm, 2003). Frahm (2003) indicated that about two-thirds of all bryophyte species (mosses, hornworts, and liverworts) occur in the tropics. To date, however, no formal analyses of global distribution patterns have been undertaken to test the hypothesis that mosses are in fact more diverse in tropical than higher latitude regions.

Crosby \& al. (2000) recognized 12,800 moss species in their worldwide checklist. The number of species increases as new taxa are described and decreases as species are synonymized during the course of revisionary work (Touw, 1974). Given these contradictory trends, the current number is probably a pretty good, albeit rough, estimate for the total number of mosses.
The statistical analysis of broad-scale trends in biodiversity must be undertaken with care. In addition to complicating factors such as uneven sampling intensity, differing sample area sizes, and non-comparable habitats and levels of habitat heterogeneity among areas, species themselves are unequal in "biodiversity value". Some, for example, are closely related to congeners while others are more isolated; some species contain high levels of genetic diversity while others are relatively invariant. For these reasons, some have advocated alternative metrics for quantifying biodiversity that do not rely on subjective and sometimes arbitrary definitions of what constitutes a species (Faith, 1992, 1994; Vane-Wright \& al., 1991; Nixon \& Wheeler, 1992; Humphries \& al., 1995).

The primary purpose of this study was to test the hypothesis that mosses are more diverse near the equator than at higher latitudes. Data were compiled from regional checklists to estimate species richness ("taxonomic diversity"), and these were compared to geographic patterns in molecular diversity derived from nucleotide sequences from the plastid rps 4 gene and an intron in the mitochondrial nad5 gene. Two estimates of molecular diversity were compared to the species richness data: nucleotide diversity, which represents standing levels of biodiversity at the DNA level, and phylogenetic diversity (PD; Faith, 1992, 1994), which provides a phylogenetic (i.e., historical) estimate of molecular biodiversity. 
The molecular dataset utilized here to investigate moss diversity patterns was assembled for phylogenetic analyses of moss genera based on multiple loci. Names of taxa included in the analysis are provided in Appendix 2 but are omitted from presented trees because they are not relevant to the purpose of this study. Measures of clade support (e.g., bootstrap percentages, posterior probabilities) are also omitted because the biodiversity analyses explicitly take phylogenetic uncertainty into account, and the results are averaged across equally optimal trees. Topological relationships among the genera will be described in subsequent papers; we presently focus on the shape of the moss phylogenetic tree, which reflects the distribution of branch lengths on the reconstructed phylogram. These branch lengths estimate the "amount of evolution" that has occurred along internodes, and therefore permit analyses of biodiversity patterns.

\section{MATERIALS AND METHODS}

Regional checklists. - Numbers of species recorded from 86 geographic regions were obtained from checklists available in journals, on the World Wide Web (WWW), and by personal communication (Appendix 1). Subspecific taxa are not included. The area covered by each checklist was either obtained from the original publication, or was available on the WWW. In some cases (e.g., North American Pacific Northwest), the total area was estimated by adding together nested political units. When a fraction of some state, province, or country was included in the region covered by a checklist, the area was estimated as accurately as possible. Each area was assigned a geographic latitudinal center obtained from the WWW for all politically-defined regions (http://www .cia.gov/cia/publications/factbook/index.html and http:// www.netstate.com/states/index.html). In cases where regions consisted of multiple political units (e.g., Pacific Northwest), latitudinal centers were estimated from maps. Checklists of some U.S. states were obtained from relatively old sources, and species have undoubtedly been added to these lists. Although species are regularly added to regional checklists, no systematic attempt was made to update published lists to their currently accepted species counts. Only checklists dating from 1968 or later were used for U.S. states.

Statistical analysis. - The relationship between species richness and latitude was assessed by several methods that were designed to take sample area into account. For graphical purposes, the number of species per $10,000 \mathrm{~km}^{2}$ was plotted against latitude. The number of species per $10,000 \mathrm{~km}^{2}$ was itself related to sample area size, but over a broad range of sample area sizes this relationship could be ignored (see below). For statistical analyses of the latitudinal trend, regression analyses were conducted using SAS software (SAS Institute, 1991). Species counts were regressed against sample area (in $\mathrm{km}^{2}$ ) or the log of sample area, and latitudinal center. In this way, the relative contributions of sample area and latitude could be separated. Species counts per 10,000 $\mathrm{km}^{2}$ were also regressed against latitude. Variations in how the regressions were conducted did not affect inferences about latitudinal trends in species diversity, so only the regressions of species richness on log sample area and latitude are presented.

Molecular dataset. - Nucleotide sequences for the chloroplast encoded $r p s 4$ gene and the mitochondrial encoded nad5 intron were obtained from 556 moss accessions representing 555 different genera. All of the major lineages of mosses were sampled; the dataset includes a species from $64 \%$ of all moss genera recognized by Crosby \& al. (2000). Herbarium voucher information and GenBank accession numbers for all sequences are provided in Appendix 2. Protocols for DNA extraction and sequencing of these regions, including primer information, were given by Cox \& al. (2004).

Phylogenetic analyses. - Analyses of the 556taxon dataset were conducted using Bayesian statistical inference. Heterogeneous Bayesian analyses were performed using MrBayes3 (Huelsenbeck \& Ronquist, 2002). Separate substitution models were applied to each codon position at the rps 4 locus and for the nad5 intron region. The appropriate substitution models were determined by hierarchical likelihood ratio tests with the aid of MrModeltest 1.1b (Nylander, 2002). Bayesian analyses were conducted starting from a "usertree" calculated using the Neighbor-joining algorithm under maximum likelihood distances in PAUP (Swofford, 2001) with $10,000,000$ generations using default, uniform priors. Model parameters including trees were sampled every $500^{\text {th }}$ generation. The number of trees needed to reach stationality (i.e., the "burnin") in the MCMC algorithm was estimated by visual inspection of the plot of ML score at each sampling point using Excel (Microsoft Corp.). Trees of the burnin (i.e., those before the chain reached stationality) for each run were excluded from the tree set, and the trees from each run were combined to form the full sample of trees assumed to be representative of the posterior probability (p.p.) distribution. 19,200 trees were saved from the Bayesian analyses. This tree set was filtered using the FILTER command of PAUP to include only those trees that were compatible with well-supported nodes relating the same taxa included in the backbone topology of moss relationships described by Cox \& al. (2004). Topological details and support for each node will be presented in subsequent papers. 
Molecular biodiversity. - Each accession was assigned to one of three latitudinal zones based on where it was collected. Collections from north of $30^{\circ} \mathrm{N}$ latitude were considered "Northern Hemisphere", those from between $30^{\circ} \mathrm{S}$ and $30^{\circ} \mathrm{N}$ were assigned to the "Tropical" zone, and those collected south of $30^{\circ} \mathrm{S}$ were considered "Southern Hemisphere." Although it is acknowledged that not all habitats between $30^{\circ} \mathrm{N}$ and $30^{\circ} \mathrm{S}$ are ecologically tropical (e.g., high elevation sites), characterizing each site climatically or vegetationally was neither possible in all cases, nor fully objective. The same scoring approach was used by Shaw \& al. (2003a).

Accessions included in the molecular analyses were selected to represent moss genera for purposes of resolving phylogenetic relationships. However, most genera of mosses have at least one species that occurs in each of the zones. Thus, most genera could not be assigned to one and only one zone. Indeed, many of the species included in these analyses are distributed across more than one of our three latitudinal zones. Biogeographic patterns are therefore based on the accessions themselves rather than the genera (or even species) they represent. The accessions represent random samples from each of the three latitudinal zones. The estimates of phylogentic diversity, described below, therefore test the null hypothesis that random samples of mosses from the three latitudinal zones contain the same (i.e., indistinguishable) levels of molecular biodiversity.

Nucleotide variation and diversity. Analysis of molecular variance (AMOVA) was used to estimate components of molecular variance among versus within latitudinal zones, and test for significant genetic differentiation among samples from the zones. AMOVA addresses the hypothesis that nucleotide frequencies are non-uniform among latitudinal zones. Nucleotide diversity within each latitudinal zone was estimated from the sample of sequences representing that region using ARLEQUIN (Schneider \& al., 2000).

Phylogenetic diversity. - Phylogenetic diversity (PD; Faith, 1992) was estimated on 10 randomly selected trees from the posterior probability distribution with branch lengths optimized under a General TimeReversible substitution model with a discrete gamma distribution of rate (four categories) and a proportion of invariant characters $(\mathrm{GTR}+\mathrm{I}+\mathrm{G})$. PD utilizes information inferred from phylogenetic relationships among accessions included in the dataset. PDs for each geographic region were estimated as the total length of the minimum-spanning subtree connecting all accessions representing that region. The sum of all branch lengths on the object tree constitutes the total PD contained in our sample. Partitioning of PD among regions was estimated by deleting all taxa other than those in the region of interest, and branch lengths were again summed for the remaining subsample.

PD is based on total (i.e., cumulative) branch length for each geographic region, so estimates are affected by sample sizes. The substantial differences in sample sizes among regions (see Table 1) make the effect of sample size potentially significant. In order to correct for differing sample sizes among geographic regions and make direct comparisons possible, PDs were estimated for randomly sampled subsets of the Northern and Tropical accessions at $\mathrm{N}=87$, the size of our Southern Hemisphere sample. PD was recalculated for each of 100 taxon subsamples (of $\mathrm{N}=87$ ), so that we could estimate PD based on sample sizes equivalent to the least extensively sampled region (Southern Hemisphere). This subsampling procedure assessed the effect of which Northern Hemisphere accessions we used to estimate PD for the region. In order to account for phylogenetic uncertainty, which can also affect PD estimates, this subsampling procedure was repeated on each of 10 randomly selected trees from the Bayesian posterior probability distribution.

Differences in PD among regions were tested by analysis of variance (ANOVA), implemented in SAS. The model included latitudinal region $(\mathrm{N}=3)$ and tree $(\mathrm{N}$ $=10)$ as main effects, with error variances provided by taxon subsamples. The model was unbalanced because estimates for Northern Hemisphere and Tropical regions had 100 taxon subsample replicates whereas the Southern Hemisphere region had no such replication. Variance components attributable to the main effects were estimated using the VarComp procedure in SAS, using the ML option.

\section{RESULTS}

Global patterns in species richness. Numbers of species, sample areas, and the latitudinal centers for each area used to analyze species richness patterns are shown in Appendix 1. Species richness is, not surprisingly, significantly related to the size of the area covered by checklists (Fig. 1). In addition, there are more species per unit area $\left(10,000 \mathrm{~km}^{2}\right)$ in the largest sample areas compared to smaller areas (Fig. 2). The trend is not strong except for the largest areas, possibly because these areas encompass an exceptionally broad

Table 1. Nucleotide diversity in Northern Hemishere (> $\left.30^{\circ} \mathrm{N}\right)$, tropical, and Southern Hemisphere (>30 $\mathrm{S}$ ) accessions.

\begin{tabular}{lcc}
\hline Region & Sample size & Nucleotide diversity \\
\hline Northern Hemisphere & 224 & $0.057214 \pm 0.027320$ \\
Tropical & 245 & $0.057601 \pm 0.027491$ \\
Southern Hemisphere & 87 & $0.062655 \pm 0.030116$ \\
\hline
\end{tabular}




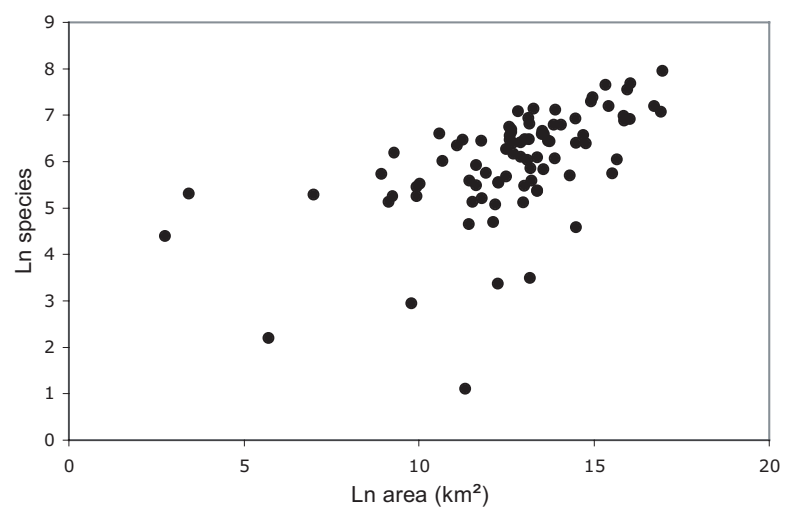

Fig. 1. Plot of species number versus (log) sample area.

range of climatic zones and topographic features; for example, North America north of Mexico, which includes subtropical to high arctic habitats. The size of the sample area and scale at which biodiversity occurs can have a strong effect on analyses of this type.

When no sample areas are excluded from the analysis, some samples from low latitudes had the highest numbers of species, but other tropical areas had much lower species richness (Fig. 3). The relationship between species richness and latitude is not significant when sample area is taken into account, but the trend is apparent from the fact that the latitude effect is nearly significant (Table 2).

To test whether a latitudinal pattern is obscured by the largest sample areas, these were separated from smaller sample areas and the two groups were analyzed separately. However, the effect of latitude is not significant for either the large sample area dataset (Fig. 4; Table 2) or the smaller sample area dataset (Fig. 5; Table 2). Various other subsets of the data based on area sizes were analyzed separately, but the latitudinal effect was not significant in any regression. Some of the samples from the tropical zone were from desert countries of northern

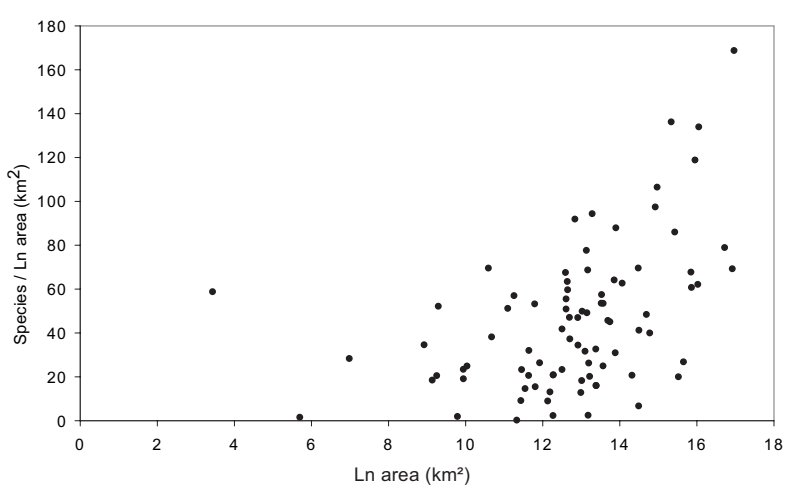

Fig. 2. Plot of number of species per unit area versus sampling area size included in moss checklists.

Africa, for example, where the flora is incompletely known and the dry climate may obscure a general latitudinal pattern. Nevertheless, even when these countries (Cyprus, Israel, Jordan, Kuwait, Lebanon, Oman, Syria, United Arab Emirates) plus the smallest sample areas (Hong Kong, Maldive Islands, Simeonof Island [Alaska], and Barro Colorado Island [Panama]) were excluded, the latitudinal affect was not significant. However, when only samples from North, Central, and South America were included, the latitudinal effect was significant (Table 2).

Nucleotide diversity. - Molecular diversity is lowest in the Northern Hemisphere, intermediate in the tropical zone, and highest in the Southern Hemisphere, but standard errors of nucleotide diversities are high (as is typical of such estimates) and the differences are small (Table 1). The AMOVA shows that there is virtually no molecular differentiation between accessions from the three latitudinal zones (Table 3). Indeed, almost $99 \%$ of the total diversity at the rps 4 and nad5 loci exists within latitudinal zones.

Moss phylogenetic relationships and geographic patterns. - A randomly selected tree from

Table 2. Effects of sampling area size and latitude on species richness estimates for mosses, based on linear regression. D.f. $=$ degrees of freedom. F = test statistics of ANOVA; Pr > F probability of observing an F of that magnitude (or greater) by chance alone.

\begin{tabular}{|c|c|c|c|c|c|}
\hline Source & D.f. & Type III sum of squares & Mean square & F value & $\operatorname{Pr}>\mathbf{F}$ \\
\hline \multicolumn{6}{|l|}{ All data: } \\
\hline Ln area & 1 & 7775504.0414 & 7775504.0414 & 43.63 & 0.0001 \\
\hline Latitude & 1 & 600635.3623 & 600635.3623 & 3.37 & 0.0700 \\
\hline \multicolumn{6}{|c|}{ Sampling areas $>1,000,000 \mathrm{~km}^{2}$} \\
\hline Ln area & 1 & 3422309.9092 & 3422309.9092 & 11.00 & 0.0033 \\
\hline Latitude & 1 & 866532.0605 & 866532.0605 & 2.79 & 0.1099 \\
\hline \multicolumn{6}{|c|}{ Sampling areas $>10,000$ and $<1,000,000 \mathrm{~km}^{2}$} \\
\hline Ln area & 1 & 666262.80387 & 666262.80387 & 8.84 & 0.0044 \\
\hline Latitude & 1 & 33291.14159 & 33291.14159 & 0.44 & 0.5091 \\
\hline \multicolumn{6}{|c|}{ North, Central, and South American sampling areas } \\
\hline Ln area & 1 & 2594762.2561 & 2594762.2561 & 24.02 & 0.0001 \\
\hline Latitude & 1 & 1573547.2541 & 1573547.2541 & 14.57 & 0.0007 \\
\hline
\end{tabular}




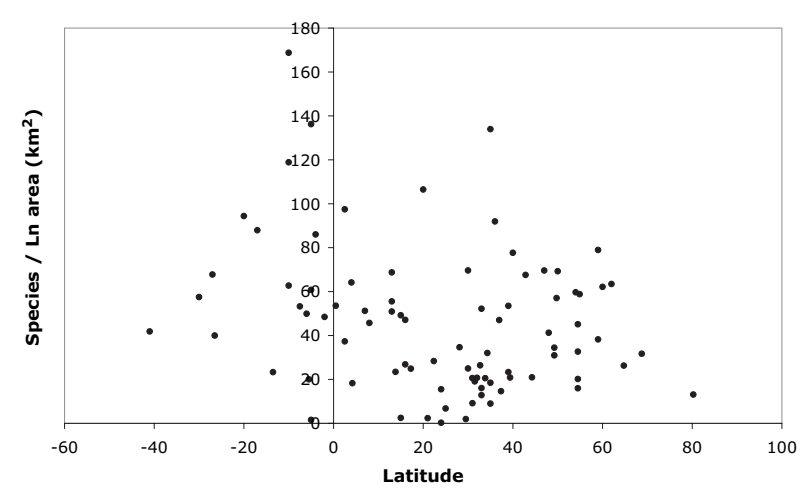

Fig. 3. Species richness per unit area $\left(10,000 \mathrm{~km}^{2}\right)$ versus latitude.

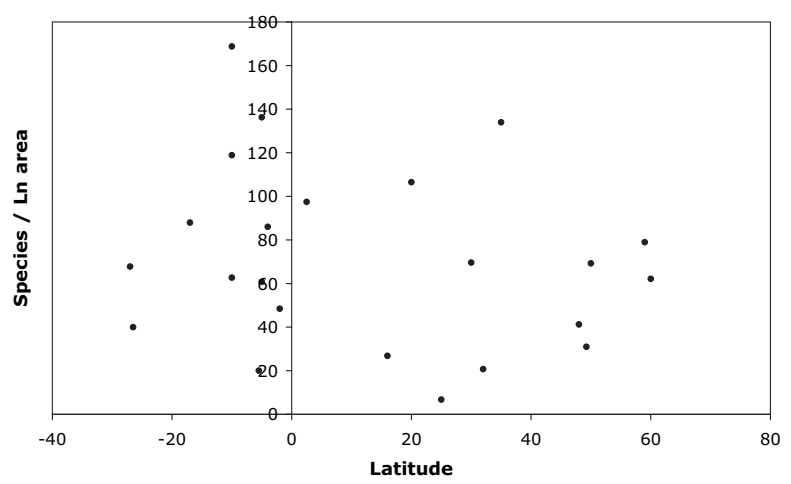

Fig. 4. Species richness per unit area versus latitude from checklists for areas $>1,000,000 \mathrm{~km}^{2}$.

the Bayesian posterior probability space on which the phylogenetic diversity analyses were conducted is shown as Fig. 6. The tree has a characteristic shape that has been documented in previous studies (Cox \& al., 2004); internode branch lengths are fairly consistent until the origin of hypnalian pleurocarps, after which they are abruptly short (Fig. 6). The sister group to Hypnales, Hookeriales, does not exhibit short branch lengths that characterize Hypnales (Fig. 6). Other small regions of the tree suggest more local changes in diversification rate, or substitution rate, or both (e.g., a clade that includes seven genera of Polytrichaceae [Notologotrichum, Polytrichadelphus, Meiotrichum, Polytrichastrum, Oligotrichum, Atrichum, Psilopilum, Dawsonia, Polytrichum]: marked I in Fig. 6; a haplolepideous clade that includes Syrrhopodon, Mitthyridium,

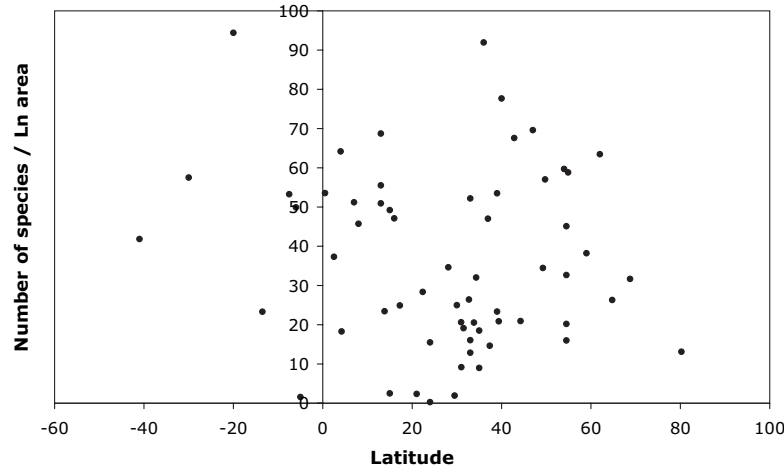

Fig. 5. Species richness per unit area versus latitude from checklists for areas $<1,000,000 \mathrm{~km}^{2}$.

Anthrocormus, Exodictyon: short arrow in Fig. 6A).

Accessions from Northern Hemisphere, Tropical, and Southern Hemisphere localities are rather scattered throughout the moss phylogenetic tree (not shown). Nevertheless, some groups, such as Hookeriales, are clearly most diverse in tropical regions. The moss phylogeny therefore reflects both the efficacy of dispersal, and evolutionary radiations following dispersal.

Phylogenetic diversity. - PD estimates follow the same pattern as standing nuclear diversity: Southern Hemisphere $>$ Tropical $>$ Northern Hemisphere (Table 4). An analysis of variance for PD estimates indicates that although the differences among regions in PD are small, they are significant and account for $64 \%$ of the total variation in PD (Table 5). One possible explanation for the relatively high PD in Southern Hemisphere accessions is that Southern Hemisphere harbors early diverging and relatively isolated taxa. On average, Southern Hemisphere taxa are indeed closer to the root of the moss phylogeny, although the standard deviations associated with these estimates are large and overlapping (Table 6).

\section{DISCUSSION}

This study provides only weak evidence that the tropics are richer in moss species than are high latitude regions, although there is a statistically significant relationship between species numbers and latitude for New World floras. Our inference from this exercise is that moss diversity, measured by the numbers of species, is

Table 3. Analysis of molecular variance in rps4 and nad5 sequences among accessions collected from three major latitudinal zones (Northern Hemisphere, Tropical, Southern Hemisphere).

\begin{tabular}{lrccc}
\hline Source of variation & D.f. & Sum of squares & Variance component & Percentage of variation \\
\hline Among geographic regions & 2 & 313.535 & 0.63958 & 1.35 \\
Within geographic regions & 553 & 25825.413 & 46.70057 & 98.65 \\
Total & 555 & 26138.948 & 47.34015 & \\
\hline
\end{tabular}




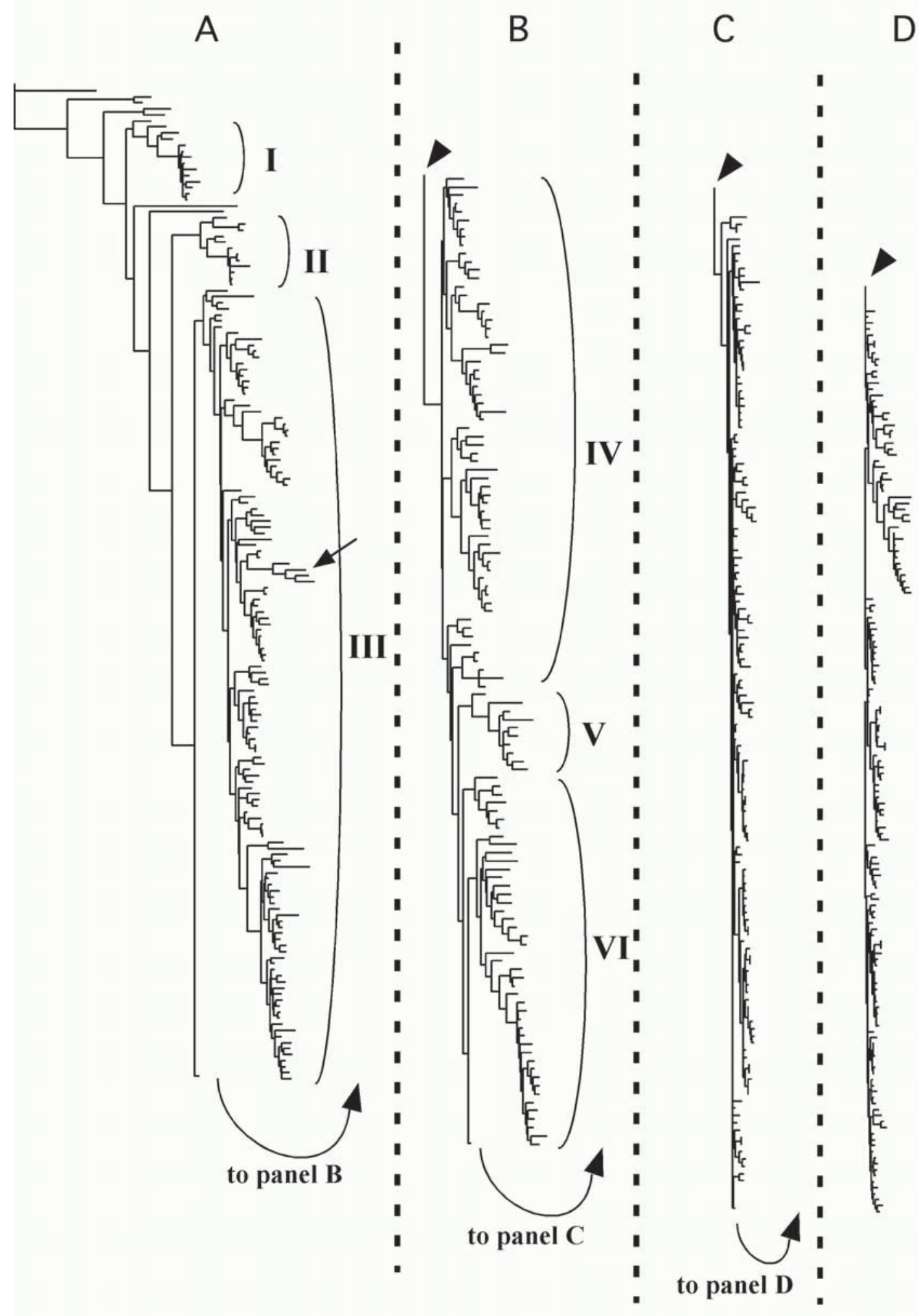

Fig. 6. Phylogenetic relationships among 550 genera of mosses based on rps4 (cpDNA) and nad5 intron (mtDNA) sequences, showing the general shape of the tree. Note that branch lengths in the Hypnales (panels $C$ and $D$ ) are exceptionally short. This tree was randomly selected from the Bayesian posterior probability space. I = Polytrichaceae, II = Funariales and Encalyptales, III = haplolepideous mosses, IV = acrocarpous (and cladocarpous) taxa with diplolepideous-alternate peristomes, $V=$ Garovagliales, and VI = Hookeriales. Panels $C$ and D are all Hypnales. 
Table 4. Phylogenetic diversity (PD) in Northern Hemishere $\left(>30^{\circ} \mathrm{N}\right)$, tropical, and Southern Hemisphere $\left(>30^{\circ}\right.$ S) accessions.

\begin{tabular}{lll}
\hline Region & Sample & PD ( \pm standard deviation) \\
\hline Northern Hemisphere & 1000 & $2.2027276 \pm 0.1577044$ \\
Tropical & 1000 & $2.4655070 \pm 0.1136834$ \\
Southern Hemisphere & 1000 & $2.6576010 \pm 0.0100686$ \\
\hline
\end{tabular}

probably highest in the tropics, but the pattern is not striking. The lack of an obvious pattern is itself noteworthy. A pronounced latitudinal gradient is well-known for angiosperms (Gentry, 1988) and has been evident for over 100 million years (Crane \& Lidgard, 1989). Many early botanists accepted the center of diversity $=$ center of origin hypothesis put forth by Willis (1922) but it is now widely accepted that high levels of species diversity may reflect relatively low regional extinction rather than a center of origin (Stebbins, 1974).

Latitudinal gradients in species richness have been documented for a broad range of plants and animals (Rosenzweig, 1995), and most of the earth's top 25 biodiversity hotspots are in the tropics (Meyers \& al., 2000). Tropical rainforests are said to contain very high levels of angiosperm diversity. The moss flora of Amazonia, in contrast, is notably depauperate (Churchill, 1998). There are high levels of moss diversity in tropical mountains (Churchill \& Linares, 1995), as in many other organisms (Churchill \& al., 1995), but the numbers presently available for mosses do not support the view that tropical mountain systems, including the Andes, are obviously richer than some regions at higher latitudes. In one of the only other studies to attempt a test of increasing moss diversity toward the equator, Vitt (1991) found no such diversity gradient among South Pacific Islands.

The analysis of broad-scale trends in species richness is fraught with methodological and statistical difficulties (Conner \& McCoy, 1979; Rahbek, 1995, 1997). The confounding effects of area are substantial, and area itself may be the primary explanation underlying both altitudinal and latitudinal gradients (Terborgh, 1977; Rosenzweig, 1995). In addition, regions within a latitudinal zone are ecologically heterogeneous because of differences in, for example, rainfall, humidity, and topography. Regions within latitudinal zones also differ in history, which can be an important determinant of species richness. In fact, the general absence of a clear latitudi- nal trend in the current study may be due in part to ecological and historical variation among sampling regions within latitudinal zones. Attempts were made to explore this possibility for mosses by examining subsets of the data, but except for a significant but weak trend in the Americas, we were not able to tease out a clear latitudinal pattern from any subset of the data. Despite all the weaknesses in our data, we would expect to see a trend if the global latitudinal patterns were strong. They are not, at least not at the geographic/ecological scales at which floristic data provide insight.

Areas covered by the moss checklists differ in sampling intensity; that is, how completely known the flora is. Tropical moss floras are obviously less intensively sampled than are at least the Northern Hemisphere areas, and species richness is almost certainly higher in the tropics than current numbers suggest. Nevertheless, the numbers would have to change relatively much for a clear pattern to emerge; moreover, the same inequality of floristic knowledge is true of angiosperms and most other organisms. Incomplete sampling is unlikely to explain the lack of a clear latitudinal gradient in moss species richness.

Another factor that could affect our ability to detect latitudinal trends is the superimposed patterns of diversity at different scales. Beta (regional) diversity could be higher in tropical moss flora even though alpha (local) diversity is not. The moss flora of Costa Rica might not include an exceptionally high number of species, but there might be higher species turnover between Costa Rica and Mexico than, for example, between Montana and California. Our data are not sufficient to address this issue because the analyses are based on species numbers alone for each region; additional studies in which the primary data are species lists are needed so that floristic turnover among sampling areas could be evaluated.

There are some exceptions to the general trend of increasing biodiversity toward the equator, and organism body size appears to be related to the magnitude (or existence) of the latitudinal gradient (Hillebrand \& Azovsky, 2001). Small species tend to have cosmopolitan distributions and the slopes of species-area curves decrease with body size (Fenchel \& Finlay, 2004). Microorganisms represent the extreme case, in which population sizes are so huge that "everything is everywhere" (Fenchel \&

Table 5. Analysis of variance in phylogenetic diversity (PD) for accessions collected from three major latitudinal zones (Northern Hemisphere, Tropical, Southern Hemisphere), and among ten randomly selected trees from the $95 \%$ posterior probability space of a Bayesian phylogenetic analysis. $F=$ test statistics of ANOVA.

\begin{tabular}{lrcccc}
\hline Source & D.f. & Sum of squares & Mean square & F value & \% variation \\
\hline Region & 2 & 35.56770175 & 17.78385088 & 942.81 & $64 *$ \\
Tree & 9 & 0.07033818 & 0.00781535 & 0.41 & 0 \\
Error & 1998 & 37.68748939 & 0.01886261 & 36 & \\
\hline
\end{tabular}


Table 6. Mean (+ standard deviation) number of nodes from the phylogenetic root of mosses for accessions from three major latitudinal zones.

\begin{tabular}{ll}
\hline Northern Hemisphere & $24.69196+9.54286$ \\
Tropical & $27.36327+9.07046$ \\
Southern Hemisphere & $21.63218+9.25494$ \\
\hline
\end{tabular}

Finlay, 2004). Hillebrand \& Azovsky (2001) posit that community patterns of species diversity in big organisms are determined by large-scale and long-term processes such as speciation rates and patterns, biogeography, and history, whereas communities of small organisms may be more influenced by ecological processes such as competition and other biotic interactions. In other words, assemblages of large organisms are "unsaturated" and are limited by dispersal (i.e., who got there-biogeography, history), whereas assemblages of smaller organisms are not so dispersal limited. At the level of taxonomic species, mosses do not display the "everything is everywhere" biogeographic extreme, but it is well known that moss distributions tend to be much broader, on average, than are those of angiosperms. Mosses fit the pattern of a relationship between body size, apparent dispersal ability, and strength of the latitudinal gradient.

Another factor that can affect inferences about biodiversity patterns are species delimitations. Clearly, not all species "were created equally" with regard to biodiversity value. Species that are part of a recent radiation may be very closely related genetically, even if morphologically distinct (e.g., Baldwin, 1997; Meyer, 1993). Moreover, some species contain high levels of genetic diversity while others are depauperate. How do broad scale biodiversity patterns based on species richness compare to patterns based on molecular diversity? At least in the moss genus, Sphagnum, the patterns can be quite different (Shaw \& al., 2003a).

Nucleotide and phylogenetic diversity show congruent, even if subtle, geographic trends. A random sample of tropical mosses has higher molecular diversity than a comparable Northern Hemisphere sample, but Southern Hemisphere accessions have the highest diversity. The patterns in phylogenetic diversity are significant, but the degree of molecular differentiation among regions is very minor: about $1 \%$ of the total diversity among mosses at the two loci sampled in our study. Moreover, the statistical analysis of PD should be interpreted with caution since the Southern Hemisphere estimate did not incorporate taxon subsampling. Our results are clear, however, in showing that phylogenetic uncertainty contributes little to the variance in PD estimates, at least in this study where the phylogenetic tree was relatively well resolved and statistically supported (such that equally optimal trees were very similar in both shape and topology).
The fact that there is little differentiation in mitochondrial and plastid DNA (for the loci we sampled) between broad geographic regions across a clade that is several hundred million years old demonstrates that there has been substantial inter-regional migration. Tropical accessions are found throughout our phylogenetic reconstruction for the mosses, and few clades are completely restricted to particular latitudinal zones. These observations attest to the migratory prowess of mosses; every major and most minor lineages of mosses have successfully dispersed between northern, tropical, and southern latitudinal zones. On the other hand, some nonrandom geographic clustering of accessions also indicates that radiations have followed some dispersal events. Species level phylogenies for smaller clades are required to further elucidate such evolutionary patterns. Nevertheless, because of extensive dispersal at a global scale, mosses as a whole come close to displaying the "everything is everywhere" pattern at the nucleotide level. Perhaps it is not therefore surprising that the latitudinal trend in moss diversity is weak, at best.

There is suggestive evidence that moss molecular diversity might be higher in the Southern Hemisphere than in either the tropics or the Northern Hemisphere. The difference in phylogenetic diversity is significant, and the same pattern is present for nucleotide diversity estimates. Even if the pattern is real, the basis for it is obscure. Our analyses suggest that two randomly selected Southern Hemisphere accessions are, on average, more distinct in terms of DNA sequences than are randomly selected tropical or Northern Hemisphere samples.

One possible explanation is that mosses are older in the Southern Hemisphere, raising the possibility that they originated there. This hypothesis is difficult to test by reconstructing geographic ranges on the generic phylogeny because most moss genera span more than one of the latitudinal zones that we have defined. The Sphagnopsida are cosmopolitan, although it appears that the early diverging lineages of Sphagnopsida are Southern Hemisphere and/or tropical (Shaw \& al., 2003b). The two species of Takakia are both Northern Hemisphere; Andreaeopsida are most diverse in the Southern Hemisphere, but there are species from the subantarctic to the arctic. The only clear pattern is that none of the early diverging lineages of mosses are primarily tropical, but no other inferences are presently possible. Only a species-level phylogeny for the mosses, in which early-diverging species of all major clades are identified, might be capable of resolving the geographic origin of mosses. Our results, including the observation that Southern Hemisphere accessions tend to be closer to the root of the moss phylogeny, are consistent with a Southern Hemisphere origin. 


\section{ACKNOWLEDGEMENTS}

This study was supported by NSF grants DEB-0089131 to AJS and DEB-0089633 to BG.

\section{LITERATURE CITED}

Anderson, L. E., Crum, H. A. \& Buck, W. R. 1990. List of the mosses of North America north of Mexico. Bryologist 93: 448-499.

Argent, G. C. G. 1979. The systematics of tropical bryophytes. Pp. 185-193 in: Clarke, G. C. S. \& Duckett, J. G. (eds.), Bryophyte Systematics. Academic Press, London.

Baldwin, B. G. 1997. Adaptive radiation of the Hawaiian silverword alliance: congruence and conflict of phylogenetic evidence from molecular and non-molecular investigations. Pp. 103-128 in: Givnish T. J. \& Sytsma, K. J. (eds.), Molecular Evolution and Adaptive Radiation. Cambridge Univ. Press, New York.

Bird, C. D. 1973. A New Catalogue of the Bryophytes from Alberta, Saskatchewan, and Manitoba. Univ. Calgary, Calgary.

Born, S., Frahm, J.-P. \& Pócs, T. 1993. A new checklist of the Mosses of Central Africa. Trop. Bryol. 8: 223-273.

Brassard, G. R. 1971. The mosses of northern Ellesmere Island, arctic Canada. II. Annotated list of taxa. Bryologist 74: $282-311$.

Brassard, G. R. 1983. Checklist of the mosses of the island of Newfoundland, Canada. Bryologist 86: 54-63.

Churchill, S. P. 1998. Catalog of Amazonian mosses. J. Hattori Bot. Lab. 85: 191-238.

Churchill, S. P., Balslev, H., Forero, E. \& Luteyn, J. L. (eds.). 1995. Biodiversity and Conservation of Neotropical Montane Forests. New York Bot. Garden, New York.

Churchill, S. P., Griffin, D. III \& Muñoz, J. 2000. A checklist of the mosses of the tropical Andean countries. Ruizia 17: 1-203.

Churchill, S. P. \& Linares, E. L. 1995. Prodromus Bryologiae Novo-Granatensis. Part 1. Instituto de Ciencias Naturales, Museo de Historia Natural, Univ. Nacional de Colombia, Bogota.

Conner, E. F. \& McCoy, E. F. 1979. The statistics and biology of the species area relationship. Amer. Nat. 113: 791-833.

Cox, C. J., Goffinet, B., Shaw, A. J. \& Boles, S. 2004. Phylogenetic relationships among the mosses based on heterogeneous Bayesian analysis of multiple genes from multiple genomic compartments. Syst. Bot. 29: 234-250.

Crane, P. R. \& Lidgard, S. 1989. Angiosperm diversification and paleolatitudinal gradients in cretaceous floristic diversity. Science 246: 675-678.

Crosby, M. R., Magill, R. E., Allen, B. \& He, S. 2000. A Checklist of the Mosses. Missouri Botanical Garden, St. Louis, Missouri, U.S.A. http://www.mobot.org/MOBOT/ tropicos/most/checklist.shtml

Crosby, M. R., Schultze-Motel, U. \& Schultze-Motel, W. 1983. Katalog der Laubmoose von Madagaskar und den umliegenden Inseln. Willdenowia 13: 187-255.
Dirkse, G. M., Bouman, A. C. \& Losada-Lima, A. 1993. Bryophytes of the Canary Islands, an annotated checklist. Cryptog., Bryol. Lichén. 14: 1-47.

Eggers, J. 1982. Artenliste der Moose Makaronesiens. Cryptog., Bryol. Lichén. 3: 283-335.

Faith, D. P. 1992. Conservation evaluation and phylogenetic diversity. Biol. Conserv. 61: 1-10.

Faith, D. P. 1994. Phylogenetic diversity: a general framework for the prediction of feature diversity. Pp. 251-268 in: Forey, P. L., Humphries, C. J. \& Vane-Wright, R.I. (eds.), Systematics and Conservation Evaluation. Clarendon, Oxford.

Fenchel, T. \& Finlay, B. J. 2004. The ubiquity of small species: patterns of local and global diversity. Bioscience 54: 777-784.

Fife, A. J. 1995. Check-list of the mosses of New Zealand. Bryologist 98: 313-337.

Florschutz-de Waard, J. 1990. A catalogue of the bryophytes of the Guianas. II. Musci. Trop. Bryol. 3: 89-104.

Flowers, S. 1973. Mosses of Utah and the West. Brigham Young Univ., Provo, Utah.

Frahm, J.-P., O'Shea, B., Pócs, T., Koponen, T., Piippo, S., Enroth, J., Rao, P. \& Fang, Y.-M. 2003. Manual of Tropical Bryology. Trop. Bryol. 23: 1-196.

Frey, W. \& Kürschner, H. 1991. Conspectus Bryophytorum Orientalum et Arabicorum. An annotated catalogue of the bryophytes of southwest Asia. Bryophyt. Bibl. 39: 1-181.

Gentry, A. H. 1988. Tree species richness of upper Amazonian forests. Proc. Nat. Acad. Sci. U.S.A. 85: 156-159.

He, S. 1998. A checklist of the mosses of Chile. J. Hattori Bot. Lab. 85: 103-189.

Hermann, F. J. 1976. Recapilación de los musgos de Bolivia. Bryologist 79: 125-171.

Higuchi, M. \& Nishimura, N. 2003. Mosses of Pakistan. J. Hattori Bot. Lab. 93: 273-291.

Hillebrand, H. \& Azovsky, A. I. 2001. Body size determines the strength of the latitudinal diversity gradient. Ecography 24: 251-256.

Huelsenbeck, J. P. \& Ronquist, F. 2002. MrBayes Version 3.0B. Available from the authors: http://morphbank.ebc.uu .se/mrbayes3/info.php.

Humphries, C. J., Williams, P. H., \& Vane-Wright, R. I. 1995. Measuring biodiversity value for conservation. Annu. Rev. Ecol. Syst. 26: 93-111.

Ignatov, M. S. \& Ofanina, O. M. 1992. Check-list of mosses of the former USSR. Arctoa 1: 1-85.

Ireland, R. R., Bird, C. D., Brassard, G. R., Schofield, W. B. \& Vitt, D. H. 1980. Checklist of the Mosses of Canada. National Museums of Canada, Ottawa.

Ireland, R. R. \& Cain, R. F. 1975. Checklist of the mosses of Ontario. Nat. Mus. Can. Pub. Bot. 5: 1-67.

Iwatsuki, Z. 1991. Catalog of the Mosses of Japan. Hattori Botanical Laboratory, Nichinan.

Iwatsuki, Z. \& Tan, B. C. 1979. Checklist of Philippine mosses. Philippine J. Biol. 8: 179-210.

Kis, G. 1985. Mosses of South-East Tropical Africa. Inst. Ecology Bot. Hungarian Acad. Sci. 1-170.

Kucera, J. \& Vána, J. 2003. Check- and red-list of bryophytes of the Czech Republic. Preslia, Praha 75: 193-222.

Lampton, K. R. 1970. Mosses of Georgia: a checklist of species which have been collected within the state. Bull. Georgia Acad. Sci. 28: 81-98. 
Lawton, E. 1971. Moss Flora of the Pacific Northwest. Hattori Botanical Laboratory, Nichinan.

Magill, R. E. \& Schelpe, E. A. 1979. The bryophytes of Southern Africa. Mem. Bot. Surv. S. Afr. 43: 1-39

McCleary, J. A. \& Green, V. V. 1971. A checklist of Idaho mosses. Bryologist 74: 175-180.

Menzel, M. 1991. Listado básico de la flora Salvadorensis. Bryophyta. Cuscatlania 1(5): 1-24.

Menzel, M. 1992. Preliminary check-list of the mosses of Peru (Studies on Peruvian Bryophytes IV). J. Hattori Bot. Lab. 71: $175-254$.

Menzel, M. \& Passow-Schindhelm, R. 1990. The mosses of the Maldive Islands. Cryptog., Bryol. Lichén. 11: 363-367.

Meyer, A. 1993. Phylogenetic relationships and evolutionary processes in East African cichlid fishes. Trends Ecol. Evol. 8: 267-305.

Myers, N., Mittermeier, R. A., Mittermeier, C. G., Fonseca, G. A. B. da \& Kent, J. 2000. Biodiversity hotspots for conservation priorities. Nature 403: 853-858.

Nixon, K. C. \& Wheeler, Q. D. 1992. Measures of phylogenetic diversity. Pp. 216-234 in: Novacek, M. J. \& Wheeler, Q. D. (eds.), Extinction and Phylogeny. Columbia Univ. Press, New York.

Nylander, J. A. A. 2002. MrModeltest - Version 1.1b. Available from the authors. http://www.ebc.uu.se/systzoo/staff/ nylander.html.

O'Shea, B. J. 2002. Checklist of the mosses of Sri Lanka. J. Hattori Bot. Lab. 92: 125-164.

O'Shea, B. J. 2003. Bryogeographic relationships of the mosses of Sri Lanka. J. Hattori Bot. Lab. 93: 293-304.

Pursell, R. A. 1973. Un censo de los musgos de Venezuela. Bryologist 76: 473-500.

Rahbek, C. 1995. The elevational gradient of species richness: a uniform pattern? Ecography 18: 200-205.

Rahbek, C. 1997. The relationship among area, elevation, and regional species richness in neotropical birds. Amer. Nat. 149: 875-902.

Reese, W. D. 1972. List of the mosses of Louisiana. Bryologist 75: 290-298.

Rohde, K. 1992. Latitudinal gradients in species diversity: the searching for the primary cause. Oikos 65: 514-527.

Rosenzweig, M. L. 1995. Species Diversity in Space and Time. Cambridge Univ. Press, New York.

Salazar Allen, N., Arrocha, C. \& Chung, C. 1991. The mosses of Barro Colorado Island, Panama. Bryologist 94: 289-293.

SAS Institute. 1991. SAS Users Guide: Statistics. SAS Institute Inc., Cary, North Carolina.

Schneider, S., Roessli, D. \& Excoffier, L. 2000. ARLEQUIN ver. 2.000. http://anthro.unige.ch/arlequin.

Schofield, W. B., Talbot, S. \& Talbot, S. L. 2004. Bryophytes from Simeonof Island in the Shumagin Islands, southwestern Japan. J. Hattori Bot. Lab. 95: 155-198.

Schultze-Motel, W. 1975. Katalog der Laubmoose von WestAfrika. Willdenowia 7: 473-535.

Shaw, A. J., Cox, C. J. \& Boles, S. B. 2003a. Global patterns of peatmoss biodiversity. Molec. Ecol. 12: 2553-2570.

Shaw, A. J., Cox, C. J. \& Boles, S. B. 2003b. Polarity of peatmoss (Sphagnum) evolution: who says mosses have no roots? Amer. J. Bot. 90: 1777-1787.

Stebbins, G. L. 1974. Flowering Plants. Evolution Above the
Species Level. Harvard Univ. Press, Cambridge.

Steere, W. C. 1978. The mosses of arctic Alaska. Bryoph. Bibl. 14: 1-508.

Streimann, H. \& Klazenga, N. 2002. Catalogue of Australian Mosses. Flora of Australia Supplementary Series no. 17. Australian Biological Resources Study. Canberra.

Swofford, D. L. 2001. PAUP*: Phylogenetic Analysis Using Parsimony (*and Other Methods), vers. 4.0b8. Sinauer Associates, Sunderland, Massachusetts.

Tan, B. C. \& Iwatsuki, Z. 1991. A new annotated moss checklist. Harvard Pap. Bot. 3: 1-64.

Tan, B. C. \& Iwatsuki, Z. 1993. A checklist of Indochinese mosses. J. Hattori Bot. Lab. 74: 325-405.

Terborgh, J. 1977. Bird species diversity on an Andean elevational gradient. Ecology 58: 1007-1019.

Touw, A. 1974. Notes on taxonomic and floristic research on exotic mosses. J. Hattori Bot. Lab. 36: 123-128.

Townsend, C. \& Allen, B. H. 1998. A checklist of the mosses of Belize. Trop. Bryol. 15: 89-100.

Uyar, G. \& Cetin, B. 2004. A new check-list of the mosses of Turkey. J. Bryol. 26: 203-220.

Vane-Wright, R. I., Humphries, C. J. \& Williams, P. H. 1991. What to protect? - Systematics and the agony of choice. Biol. Conserv. 55: 235-254.

Vitt, D. H. 1973. Distributional studies on bryophytes of Alberta. Bryologist 76: 505-510.

Vitt, D. H. 1976. The mosses reported from the Yukon Territory. J. Hattori Bot. Lab. 38: 299-321.

Vitt, D. H. 1991. Distribution patterns, adaptive strategies, and morphological changes of mosses along elevational and latitudinal gradients on South Pacific islands. Pp. 205-231 in: Nimis, P. L. \& Crovello, T. J. (eds.), Quantitative Approaches to Phylogeography. Kluwer, Netherlands.

Weber, W. A. 1973. Guide to the mosses of Colorado. Inst. Arctic \& Alpine Research Occas. Pap. 6: 1-48.

Willis, J. C. 1922. Age and Area. Cambridge Univ. Press, Cambridge.

Yano, O. 1981. A checklist of Brazilian mosses. J. Hattori Bot. Lab. 50: 279-456.

Young, K. R., Ulloa Ulloa, C. \& Luteyn, J. L. 2002. Plant evolution and endemism in Andean South America: an introduction. Bot. Rev. 68: 4-21.

Zhang, L. \& Lin, P.-J. 1997. A checklist of bryophytes from Hong Kong. J. Hattori Bot. Lab. 81: 307-326. 
Appendix 1. Checklists of moss species from selected geographic regions of the world. Negative latitudes are given as negative numbers because that is how they were analyzed statistically.

\begin{tabular}{|c|c|c|c|c|}
\hline Geographical unit & Area $\left(\mathrm{km}^{2}\right)$ & Species & Latitude & Reference \\
\hline Afghanistan & 647,500 & 215 & 33.00 & Frey \& Kürschner (1991) \\
\hline Alberta & 644,392 & 437 & 54.50 & Vitt (1973) \\
\hline Amazonia & $5,500,000$ & 311 & -5.50 & Churchill (1998) \\
\hline Arctic Alaska & 487,496 & 415 & 68.75 & Steere (1978) \\
\hline Arizona & 113,642 & 373 & 34.31 & Johnson (1969) \\
\hline Australia & $7,617,930$ & 1074 & -27.00 & Streimann \& Klazenga (2002) \\
\hline Bangladesh & 133,910 & 183 & 24.00 & O’Shea (2003) \\
\hline Barro Colorado Island & 15,600 & 81 & 9.20 & Allen, Salazar, Arrocha \& Chung (1991) \\
\hline Belize & 22,806 & 250 & 17.25 & Townsend \& Allen (1998) \\
\hline Bolivia & $1,084,390$ & 1222 & -17.00 & Hermann (1976) \\
\hline Borneo & 743,330 & 724 & 0.50 & M. Suleiman \& B. Tan (pers. comm.) \\
\hline Brazil & $8,456,510$ & 1896 & -10.00 & Yano $(1981)$ \\
\hline Britain & 310,480 & 755 & 54.00 & http://rbg-web2.rbge.org.uk/bbs/Resources/uklist.htm \\
\hline British Columbia & 930,532 & 620 & 54.50 & Schofield (1968) \\
\hline California & 403,970 & 607 & 36.96 & J. Shevock (pers. comm.) \\
\hline Canada & $9,093,507$ & 996 & 60.00 & Ireland, Bird, Brassard, Schfield \& Vitt (1980) \\
\hline Canary Islands & 7,500 & 309 & 28.10 & Dirkse, Bouman \& Losada-Lima (1993) \\
\hline Central Africa & $2,398,306$ & 712 & -2.00 & Born, Frahm \& Pocs (1993) \\
\hline Central America & 522,765 & 905 & 13.00 & B. H. Allen (pers. comm.) \\
\hline Chile & 748,800 & 778 & -30.00 & He (1998) \\
\hline China & $9,326,410$ & 2,150 & 35.00 & S. He (pers. comm.) \\
\hline Colombia & $1,038,700$ & 889 & 4.00 & Churchill \& Linares (1995) \\
\hline Colorado & 268,660 & 292 & 39.00 & Weber (1973) \\
\hline Cyprus & 9250 & 169 & 35.00 & Frey \& Kürschner (1991) \\
\hline Czech Republic & 77,276 & 642 & 49.75 & Kucera \& Vána (2003) \\
\hline East Africa & $4,999,832$ & 1327 & -4.00 & Kis $(1985)$ \\
\hline El Salvador & 20,720 & 233 & 13.83 & Menzel (1991) \\
\hline Ellesmere Island & 196,235 & 160 & 80.25 & Brassard (1971) \\
\hline Estonia & 43,211 & 408 & 59.00 & http://www.zbi.ee/\%7Etomkukk/sammal.htm \\
\hline Georgia & 150,010 & 315 & 32.71 & Lampton (1970) \\
\hline Guianas & 447,470 & 238 & 4.20 & Florschütz-de Waard (1990) \\
\hline Hong Kong & 1,076 & 198 & 22.37 & Zhang \& Lin (1997) \\
\hline Idaho & 214,325 & 257 & 44.26 & McCleary \& Green (1971) \\
\hline India & $3,166,830$ & 1594 & 20.00 & O'Shea (2003) \\
\hline Indochina & $1,939,320$ & 1008 & 30.00 & O'Shea (2003) \\
\hline Iran & $1,648,000$ & 297 & 32.00 & Frey \& Kürschner (1991) \\
\hline Iraq & 437,072 & 167 & 33.00 & Frey \& Kürschner (1991) \\
\hline Israel & 20,770 & 190 & 31.50 & Frey \& Kürschner (1991) \\
\hline Italy & 294,020 & 851 & 42.83 & http://dbiodbs.univ.trieste.it/web/myxo/mosses1 \\
\hline Japan & 374,744 & 1180 & 36.00 & $\overline{\text { Iwatsuki (1991) }}$ \\
\hline Java & 132,090 & 628 & -7.50 & Tan \& Iwatsuki (1993), updated by B. Tan (pers. comm.) \\
\hline Jordan & 92,300 & 105 & 31.00 & Frey \& Kurschner (1991) \\
\hline Kuwait & 17,820 & 19 & 29.50 & Frey \& Kurschner (1991) \\
\hline Lebanon & 10,400 & 190 & 33.83 & Frey \& Kurschner (1991) \\
\hline Louisiana & 112,836 & 240 & 30.96 & Reese (1972) \\
\hline Macaronesia & 10,844 & 485 & 33.00 & Eggers (1982) \\
\hline Madagascar & 587,039 & 1254 & -20.00 & Crosby, Schultze-Motel, V. \& W. (1983) \\
\hline Malawi & 94,080 & 267 & -13.50 & http://www.nhm.ac.uk/hosted_sites/bbstbg/tbgmal.htm \\
\hline Maldive Islands & 298 & 9 & -5.00 & Menzel \& Passow-Schindhelm (1990) \\
\hline Malesia & $3,015,250$ & 1454 & 2.50 & O’Shea (2003) \\
\hline Manitoba & 549,350 & 267 & 54.50 & Bird (1973) \\
\hline New Zealand & 268,680 & 523 & -41.00 & Fife (1995) \\
\hline Newfoundland & 405,720 & 445 & 49.25 & Brassard (1983) \\
\hline North America & $18,255,430$ & 1320 & 59.00 & Anderson, Crum \& Buck (1990) \\
\hline Northern Africa & $6,268,655$ & 420 & 16.00 & R. M. Ros Espin (pers. comm.) \\
\hline Norway & 307,860 & 802 & 62.00 & http://www.nhm.uio.no/botanisk/mose/m-taxa.htm \\
\hline Oman & 212,460 & 29 & 21.00 & Frey \& Kürschner (1991) \\
\hline Ontario & $1,068,580$ & 430 & 49.25 & Ireland \& Cain (197). \\
\hline Pacific NW North Am. & $1,976,011$ & 598 & 48.00 & Lawton (1971) \\
\hline Pakistan & 778,720 & 339 & 30.00 & Higuchi \& Nishimura (2003) \\
\hline
\end{tabular}


Appendix 1 (continued.)

\begin{tabular}{|c|c|c|c|c|}
\hline Geographical Unit & Area $\left(\mathrm{km}^{2}\right)$ & Species & Latitude & Reference \\
\hline$\overline{\text { Papua NG }}$ & 452,860 & 650 & -6.00 & Tan \& Iwatsuki (1993), updated by B. Tan (pers. comm.) \\
\hline Peninsular Malaysia & 328,550 & 474 & 2.5 & Tan \& Iwatsuki (1993), updated by B. Tan (pers. comm.) \\
\hline Peru & $1,280,000$ & 882 & -10.00 & Menzel (1992) \\
\hline Phillipines & 298,170 & 642 & 13.00 & Iwatsuki \& Tan (1979), Tan \& Iwatsuki (1991) \\
\hline Phillipines (updated) & 298170 & 700 & 13.00 & Tan \& Iwatsuki (1993), updated by B. Tan (pers. comm.) \\
\hline Saskatchewan & 652,330 & 214 & 54.50 & Bird (1973) \\
\hline Saudi Arabia & $1,960,582$ & 98 & 25.00 & Frey \& Kürschner (1991) \\
\hline Simeonof Island (AK) & 31 & 202 & 54.90 & Schofield, Talbot \& Talbot (2004) \\
\hline South Yemen & 287,680 & 18 & & Frey \& Kürschner (1991) \\
\hline Southern Africa & $2,613,940$ & 591 & -26.50 & Magill \& Schelpe (1979) \\
\hline Spain & 504,750 & 1020 & 40.00 & R. M. Ros Espin (pers. comm.) \\
\hline Sri Lanka & 65,610 & 568 & 7.00 & O’Shea (2002) \\
\hline Sub-Sahara & $23,284,250$ & 2863 & -10.00 & O'Shea (2002) \\
\hline Switzerland & 39,770 & 737 & 47.00 & http://www.bryolich.ch/bryologie/ChecklisteMoose.html \\
\hline Syria & 185,180 & 109 & 35.00 & Frey \& Kurschner (1991) \\
\hline Thailand & 511,770 & 620 & 15.00 & B. Tan (pers. comm.) \\
\hline Tropical Andies & $4,561,980$ & 2089 & -5.00 & Churchill, Griffin \& Munoz (2000) \\
\hline Turkey & 780,580 & 726 & 39.00 & Uyar \& Cetin (2004) \\
\hline United Arab Emirates & 82,880 & 3 & 24.00 & Frey \& Kürschner (1991) \\
\hline USSR & $22,272,000$ & 1172 & 50.00 & Ignatov \& Ofonina (1992) \\
\hline Utah & 212,815 & 256 & 39.38 & Flowers (1973) \\
\hline Venezuela & 882,050 & 626 & 8.00 & Pursell (1973) \\
\hline Vietnam & 325,360 & 598 & 16.00 & Tan \& Iwatsuki (1993), updated by B. Tan (pers. comm.) \\
\hline West Africa & $7,727,123$ & 964 & -5.00 & Schultze-Motel (1975) \\
\hline Yemen & 527,970 & 33 & 15.00 & Frey \& Kürschner (1991) \\
\hline Yukon & 536,327 & 347 & 64.75 & Vitt (1976) \\
\hline
\end{tabular}

Appendix 2. Taxon sampling, collection information, geographic origin, and GenBank accession numbers for specimens included in the analyses of molecular moss biodiversity. $\mathbf{N}=$ Northern Hemisphere; $\mathbf{T}=$ Tropical; $\mathbf{S}=\mathbf{S o u t h e r n}$ Hemisphere. See Materials and Methods for additional information about classification of latitudinal regions.

Taxon, Collector, Collection number and (voucher location), Latitudinal region, rps4, nad5

Abietinella abietina, Schofield 103458 (DUKE), N, AY907953, AY908386; Acanthorrhynchium papillatum, Kristoferson 1990-04-17 (NY), T, AY908206, AY908468; Achrophyllum quadrifarium, Streimann 51258 (NY), S, AY449660, AY452316; Acrocladium auriculatum, Kantak \& Churchill 166 (NY), S, AY306854, AY908747; Acroporium pungens, Buck 33028 (NY), T, AY908207, AY908539; Acroschisma wilsonii, Cox 00-668 (DUKE), S, AY908011, AY908811; Actinodontium sprucei, Buck 37977 (NY), T, AY306855, AY908451; Actinothuidium hookeri, Croat 76028 (MO), N, AY908335, AY908399; Adelothecium bogotense, Vital \& Buck 19649 (NY), T, AY306856, AY452318; Aerobryidium aureo-nitens, Redfearn 2270 (MO), T, AY306857, AY908730; Aerobryopsis longissima, Streiman 57914 (MO), S, AY306859, AY908719; Aerobryum speciosum, Allen 6642 (MO), T, AY306861, AY908498; Aerolindigia cappilacea, Lineares 3721 (MO), T, AY908303, AY908511; Alophosia azorica, Rumsey s.n. (DUKE), N, AY330476, AY312867; Alsia californica, Shevock 18765 (MO), N, AY908258, AY908639; Amblytropis hispidula, Lyon 54 (MO), T, AY908609, AY908452; Amphidium lapponicum, Schofield 98089 (DUKE), N, AF222896, AY908962; Anacamptodon splachnoides, Buck 32568 (NY), N, AF143031, AY908419; Anacolia webbii, Düll 1998 (herb. Goffinet), N, AY907987, AY908949; Ancistrodes genuflexa, Holz \& Franzaring CH 00-154 (NY), S, AY306863, AY452319; Andoa berthelotiana, Hedenas 84599 (MO), N, AY908179, AY908438; Andreaea rothii, Shaw 11565 (DUKE), N, AY312866, AY312862; Anoectangium aestivum, Schofield 104414 (MO), N, AY908049, AY908832; Anomobryum julaceum, Cox s.n. (RNG), N, AF023786, AY908353; Antitrichia curtipendula, Goffinet 7829 (UCONN), N, AY908570, AY908645; Aongstroemia jamaicensis, Allen 6403 (DUKE), T, AY908094, AY908869; Aphanorrhegma serratum, Goffinet s.n. (herb. Goffinet), N, AF223048, AY908931; Aplodon wormskioldii, Nimis s.n. (herb. Goffinet), N, AY039047, AY908955; Aptychella proligera, Vital \& Buck 19448 (NY), T, AY908228, AY908474; Aptychopsis pyrophylla, Vital \& Buck 19464 (NY), T, AY908212, AY908476; Arbusculohypopterygium arbusculum, Holz \& Franzaring CH 00-80 (NY), S, AY449665, AY452366; Archidium donnellii, Risk 1536 (DUKE), N, AY908090, AY908972; Arctoa fulvella, Schofield 102571 (DUKE), N, AY908075, AY908894; Arthrocormus schimperi, Reese 17371 (DUKE), T, AY908151, AY908874; Aschisma carniolicum, Cano \& al. 7968 (MUB), N, AY908054, AY908851; Astomiopsis kienerii, Cardenas 3953 (DUKE), T, AY908072, AY908857; Atractylocarpus longisetus, Churchill \& al. 15076-a (DUKE), T, AY908126, AY908905; Atrichum undulatum, Goffinet 7605 (UCONN), N, AY908018, AY908810; Aulacomnium androgynum, Cox 149 (RNG), N, AF023811, AJ291564; Aulacopilum hodgkinsoniae, Vitt 28261 (ALTA), S, AY908116, AY908968; Baldwiniella kealeensis, Flynn 5137 (NY), T, AY908590, AY908734; Barbella cubensis, Allen 14172 (DUKE), T, AY908285, AY908722; Barbellopsis trichophora, Streimann 56092 (NY), S, AY908288, AY908723; Barbula unguiculata, Zander 1975 (BUFF), N, AF306986, AY908844; Bartramia stricta, Longton 4871 (RNG), N, AF023799, AY312870; Bartramiopsis lescurii, Schofield 99187 (MO), N, AY908019, AY908800; Beeveria distichophylloides, Fife 11150 (NY), S, AY306867, AY452320; Benitotania elimbata, Akiyama \& Suleiman 2002 (NY), T, AY449661, AY452321; Bestia vancouveriensis, Newton 5017 (herb. Newton), N, AY908328, AY908660; Bissetia lingulata, Yamaguchi 2000 (MO), N, AY908352, AY908448; Boulava mitteni, Shevock 16392 (MO), N, AY908338, AY908395; Brachelyma subulatum, Allen Font. exs. \# 87 (DUKE), N, AF306998, AY908492; Brachymenium nepalense, Long 23614 (RBG), T, AY078338. AY908354; Brachythecium salebrosum, Goffinet 4723 (DUKE), N, AF143027, AY312871; Braunfelsia dicranoides, Koponen 32555 (DUKE), T, AY908102, AY908879; Breutelia scoparia, McDowell 4039 (NY), T, AF143075, AY908382; Brothera leana, Long 21998 (DUKE), T, AY908129, AY908911; Brotherella recurvans, Buck 31506 (NY), N, AY908227, AY908470; Bryhnia novae-angliae, Buck 32561 (NY), N, AY908308, AY908523; Brymela tutezona, Salazar \& al. 13656 (NY), T, AY449662, AY908454; Bryoandersonia illecebra, Goffinet 5274 (herb. Goffinet), N, AY908317, AY908471; Bryobartramia nova-valesiae, Magill \& Schelpe 3218a (DUKE), T, AY908160, AY908967; Bryobrothera crenulata, Streimann 57716 (NY), T, AY306869, AY452325; Bryocrumia andersonii, Redfearn \& Su 971 (DUKE), T, AY908196, AY908437; Bryoerythrophyllum campylocarpum, Churchill 19042 (BUFF), T, AY908027, AY908845; Bryomaltaea obtusifolius, Allen 12284 (DUKE), T, AY908006, AY908948; Bryonorrisia acutifolia, Redfearn \& Su 1003 (DUKE), T, AY908553, AY908450; Bryostreimannia turgida, Streimann 53659 (NY), S, AY908556, AY908392; Bryoxiphium norvegicum, Norris 81646 (UC), N, AY908092, AY908957; Buxbaumia aphylla, Belland 16889 (DUKE), N, AF306959, 


\section{Appendix 2 (continued).}

Taxon, Collector, Collection number and (voucher location), Latitudinal region, rps4, nad5

AY312872; Callialaria curvicaulis, Allen 10426 (MO), N, AY908249, AY908424; Callicladium haldanianum, Schofield 97218 (MO), N, AY908561, AY908760; Callicostella pallida, Holz FG 00-14 (NY), T, AY306872, AY452328; Callicostellopsis meridensis, Griffin PV-898 (NY), T, AY306871, AY452327; Calliergon cordifolium, Rumsey 136/3 (herb. Rumsey), N, AF469844, AY908710; Calliergonella cuspidata, Schofield 105806 (MO), N, AY908183, AY908403; Calomnion complanatum, Streimann 51519 (MO), S, AY907997, AY908946; Calyptopogon mnioides, Streimann 59469 (MO), S, AY908041, AY908816; Calyptothecium praelongum, Newton \& Bell 5299, T, AY908594, AY908699; Calyptrochaeta brownii, Streimann 60613 (NY), S, AY306873, AY452329; Camptochaete arbuscula, Streimann 51516 (MO), S, AY908330, AY908658; Campyliadelphus stellatus, Lisowski B11801 (MO), N, AY908248, AY908417; Campylium chrysophyllum, Buck 32532 (NY), N, AF143048, AY908418; Campylophyllum halleri, Schofield \& al. 93659 (MO), N, AY908252, AY908433; Campylopodiella stenocarpa, Delgadillo 5002 (DUKE), T, AY908131, AY908909; Campylopus introflexus, Shaw 10490 (DUKE), S, AY908128, AY908906; Campylostelium augustifolium, Allen 22321 (MO), N, AY908147, AY908929; Canalohypopterygium tamariscinum, Frey \& Pfeiffer 98-T10C (CHR), S, AY306878, AY452331; Cardotiella subappendiculata, Arts 18/01 (herb. Goffinet), T, AY908615, AY908937; Caribaeohypnum polypterum, Dauphin 2083 (MO), T, AY908347, AY908628; Catagoniopsis berteroana, Mahu 50182 (MO), S, AY908200, AY908756; Catagonium nitens, Goffinet 5459 (herb. BG), S, AF307003, AY908473; Catharomnion ciliatum, Streimann 51423 (NY), S, AY306879, AY452332; Ceratodon purpureus, Arts REU 44/15 (DUKE), T, AY908123, AY908862; Chaetomitriopsis glaucocarpa, Wang 4046A (MO), T, AY908603, AY908681; Chaetomitrium borneense, Tan 95-1116 (NY), T, AY306880, AY452333; Chamaebryum pottioides, Venter 346 (DUKE), S, AF223051, AY908983; Cheilothela chloropus, Werner \& Ros 14024 (DUKE), N, AY908124, AY908861; Chenia leptophylla, Schafer-Verwimp 14361 (MO), T, AY908042, AY908815; Chionostomum rostratum, Redfearn 33924 (NY), T, AY908210, AY908477; Chorisodontium mittenii, Churchill \& al. 19750 (MO), T, AY908107, AY908885; Chrysoblastella chilense, Buck 39507 (DUKE), T, AY908165, AY908789; Chrysocladium flammeum, Weber B-99410 (MO), T, AY908287, AY908725; Chrysohypnum diminutivum, Churchill \& al. 20423 (MO), T, AY908345, AY908625; Cinclidotus aquaticus, Boscher \& al. (herb. Goffinet), N, AY908029, AY908843; Cirriphyllum cirrosum, Allen 19686 (MO), N, AY908310, AY908524; Cladomnion ericoides, Streimann 51478 (NY), S, AY306884, AY452336; Cladomniopsis crenato-obtusa, Buck 41360 (NY), S, AY306883, AY452335; Cladophascum gymnomitrioides, Perold 2475 (MO), S, AY908097, AY908871; Cladopodanthus speciosus, Tan 1991 (NY), T, AY908132, AY908912; Claopodium whippleanum, Shevock 19289 (DUKE), N, AY908294, AY908746; Clasmatodon parvulus, Buck 33446 (NY), N, AF143032, AY908519; Clastobryella kusatsuensis, Buck 9611 (NY), N, AY908226, AY908460; Clastobryopsis planula, Crosby 16026 (MO), T, AY908229, AY908550; Cnestrum alpestre, Buck 36198 (NY), N, AY908077, AY908896; Codonoblepharon menziesii, Shevock 18773 (herb. Goffinet), N, AY908175, AY908497; Colobodontium vulpinum, Allen 19306 (MO), T, AY908215, AY908534; Conardia compacta, Shevock 16984 (MO), N, AY908568, AY908634; Conostomum tetragonum, Goffinet 5755 (herb. Goffinet), S, AF306990, AY908954; Coscinodon calyptratus, Schofield 109633 (DUKE), N, AJ553978, AY908918; Cratoneuron filicinum, Smith 3618 (MO), N, AY908250, AY908425; Cratoneuropsis relaxa, Streimann 65232 (MO), S, AY908244, AY908427; Crosbya straminea, Fife 10379 (NY), S, AY306887, AY908490; Crossidium crassinerve, Ros 26/2/2002 (MU), N, AY908037, AY908823; Crossomitrium epiphyllum, Buck 33259 (NY), T, AY306885, AY452337; Crumia latifolia, Buck 30338 (NY), N, AY908031, AY908821; Cryptogonium phyllogonoides, Buck 7395 (NY), T, AY908598, AY908703; Cryptoleptodon longisetus, Schafer-Verwimp 4206 (MO), N, AY908260, AY908651; Cryptopapillaria penicillata, Churchill \& Betancur 16932 (NY), T, AY908292, AY908717; Cryptopodium bartramioides, Frahm 1998 (MO), S, AY907998, AY908774; Curvicladium kurzii, Akiyama 85 (NY), T, AY908266, AY908670; Curviramea mexicana, Buck 28242 (NY), T, AF143062, AY908629; Cyathophorella hookeriana, Akivama 39 (NY), T, AY306890, AY452340; Cyathophorum bulbosum, Streimann 55638 (NY), S, AY306889, AY452339; Cyclodictyon albicans, Churchill \& al. 18795 (NY), T, AY306892, AY452342; Cynodontium strumiferum, Allen 2000 (MO), N, AY908078, AY908897; Cyptodon muelleri, Vitt 27223 (NY), S, AY908586, AY908686; Cyptodontopsis obtusifolia, Akiyama 1990 (NY), T, AY908588, AY908687; Cyrtohypnum schistocalyx, Newton, Equihua \& DeLuna 4618 (herb. Newton), T, AY908336, AY908396; Cyrtopodendron vieillardii, van der Werff. \& McPherson 16072 (MO), T, AY908010, AY908768; Cyrtopus setosus, Frahm 1998 (MO), S, AY908007, AY908773; Daltonia gracilis, Buck 39508A (NY), T, AY306894, AY452344; Dawsonia superba, Kantak 582 (DUKE), S, AY908016, AY908804; Dendroalsia abietina, Goffinet 7764 (UCONN), N, AY908185, AY908459; Dendrocryphaea cuspidata, Holz \& Franzaring 00-95 (MO), S, AY908587, AY908694; Dendrocyathophorum decolyi, Matsui 7264 (NY), N, AY306896, AY452346; Dendroligotrichum dendroides, Goffinet 5425 (herb. Goffinet), S, AF306957, AY312873; Dendropogonella rufescens, Schafer-Verwimp SV/H-0478 (MO), T, AY908562, AY908708; Desmotheca apiculata, Vinas 96-4 (herb. Goffinet), T, AY908614, AY908942; Dialytrichia mucronata, DeSloover 45.173 (MO), N, AY908030, AY908830; Diaphanodon blandum, Long 18822 (DUKE), T, AY908291, AY908731; Dichelodontium nitidum, MacMillan 1/5/1999 99/14 (CHR), S, AY449664, AY452347; Dichelyma falcatum, Allen Font. exs. \# 92 (DUKE), N, AY908318, AY908493; Dichodontium pellucidum, Goffinet 7967 (UCONN), N, AY908114, AY908971; Dicnemon seriatum, Newton \& Bell 5400 (herb. Newton), T, AY908104, AY908886; Dicranella heteromalla, Goffinet 8162 (CONN), N, AY908099, AY908938; Dicranodontium meridionale, Lyon 1992 (MO), T, AY908130, AY908910; Dicranoloma eucamptodontoides, Newton \& Bell 5757 (herb. Newton), S, AY908103, AY908887; Dicranoweisia crispula, Schofield 108251 (DUKE), N, AY908164, AY908925; Dicranum scoparium, Rumsey s.n (herb. Rumsey), N, AF234158, AY908884; Didymodon rigidulus, Allred \& Allred 6443 (MO), N, AY908047, AY908828; Dimerodontium balansae, Bordas 5623 (NY), T, AY907952, AY908409; Dimorphocladon borneense, Tan 95-1060 (NY), T, AY306898, AY452348; Diphyscium foliosum, Goffinet 4492 (Pers. Herb.), N, AF223034, AY312874; Diploneuron connivens, Crosby 13732 (NY), T, AY306899, AY908457; Distichium capillaceum, Allen 9698 (MO), N, AY908162, AY908786; Distichophyllidium nymanianum, Mohamed \& Damanhuri 1118 (NY), T, AY306901, AY452350; Distichophyllum pulchellum, Streimann 51380 (NY), S, AY306902, AY452351; Ditrichum pallidum, Nelson 13749 (DUKE), N, AF306979, AY908934; Dixonia thamnoides, Akiyama Th-12 (HKY), T, AY907956, AY908469; Dolichomitra cymbifolia, Deguchi s.n. (MO), N, AY908344, AY908495; Dolichomitriopsis diversiformis, Shevock 17935 (MO), T, AY908329, AY908663; Dolotortula mniifolia, Djan-Chekan 94-71 (NY), T, AY908036, AY908824; Donnellia commutata, Allen 11883A (MO), T, AY908211, AY908536; Dozya japonica, Mizutani 13730 (DUKE), N, AY908262, AY908649; Drepanocladus aduncus, Shevock 1998 (MO), N, AY908241, AY908422; Drummondia obtusifolia, Goffinet 5586 (DUKE), S, AF223038, AY908926; Dryptodon patens, Shevock 20102 (MO), N, AY908142, AY908921; Duthiella wallichii, Redfearn 35722 (MO), T, AY908286, AY908728; Eccremidium floridanum, Allen 7505 (DUKE), T, AY908098, AY908872; Echinodium umbrosum, Streimann 49668 (NY), S, AY908269, AY908680; Ectropothecium leptochaeton, Whittemore 5594 (MO), T, AY908558, AY908405; Elmeriobryum philippinense, Koponen 33157 (DUKE), T, AY908323, AY908388; Encalypta ciliata, Schofield 98872 (DUKE), N, AY908161, AY312875; Entosthodon laevus, Goffinet 5601 (herb. Goffinet), S, AY908156, AY312876; Ephemeropsis trentepohlioides, Macmillan 95/94 (NY), S, AY306906, AY908491; Ephemerum serratum, Goffinet 4524 (herb. Goffinet), N, AY908061, AY908848; Epipterygium wrightii, Allen 6400 (MO), T, AY907985, AY908372; Eriodon conostomus, Mahu 21497 (MO), S, AY908239, AY908684; Erythrophyllopsis fuscula, Churchill \& al 19928 (MO), T, AY908028, AY908831; Eucamptodon perichaetialis, Holz \& Franzaring CH 00-119 (MO), S, AY908081, AY908899; Eulacophyllum cultelliforme, Allen 18241 (MO), T, AY908197, AY908752; Euptychium robustum, Streimann 56137 (NY), S, AY306907, AY452352; Eurhynchiella acanthophylla, Taylor 11048 (NY), S, AY908299, AY908503; Eurhynchium hians, Bachmann 327 (DUKE), N, AY908314, AY908513; Eurohypnum leptothallum, Yamaguchi 132 (MO), N, AY908203, AY908443; Eustichia longirostris, Goffinet 7091 (herb. Goffinet), S, AY908091, AY908930; Exodictyon diatatum, Newton \& Bell 5305 (herb. Goffinet), T, AY908149, AY908875; Fauriella tenuis, He \& Song 00327 (MO), T, AY908233, AY908545; Felipponea montevidensis, Wasum \& Jasper 8207(MO), S, AY908576, AY908714; Fissidens subbasilaris, Goffinet 5263 (herb. Goffinet), N, AF223056, AY312877; Fleischerobryum longicolle, Deguchi 158 (MO), N, AY907989, AY908383; Floribundaria aurea, Mizutani 15715 (MO), N, AY306910, AY908724; Flowersia campylopus, Cardenas 4369 (MO), T, AY907988, AY908788; Foreauella orthotheca, Redfearn, Magill, Crosby, Wu, Lou, Wang 34244 (NY), T, AY908560, AY908461; Forsstroemia trichomitra, Anderson 27401 (DUKE), N, AY908263, AY908650; Funaria hygrometrica, Cox s.n. (RNG), N, AF023776, Z98959; Funariella curviseta, Townsend 89/235 (E), N, AY908157, AY908791; Ganguleea angulosa, Vital \& Buck 20053 (NY), T, AY908068, AY908970; Garckea phascoides, Magill \& Pocs 11583 (MO), T, AY908096, AY908870; Garovaglia elegans, Hoffman 89-476 (NY), T, AY306915, AY452356; Gigaspermum repens, Schofield 90527 (DUKE), N, AF223049, AY908974; Glyphomitrium daviesii, Buck 14830 (NY), N, AY908082, AY908895; Glyphothecium sciuroides, 


\section{Appendix 2 (continued).}

Taxon, Collector, collection number and (voucher location), Latitudinal region, rps4, nad5

Streimann 59969 (NY), S, AY306919, AY452359; Gollania cylindricarpa, Shevock 17911 (MO), T, AY908324, AY908391; Goniobryum subbasilare, Cox \& Goffinet 63/00 (DUKE), S, AY907999, AY908775; Gradsteinia andicola, Cleef 8236(NY), T, AY908246, AY908420; Grimmia plagiopodia, Buck 39823 (NY), N, AY908144, AY908919; Groutiella tomentosa, Allen 18062 (MO), T, AY908001, AY908943; Gymnostomiella vernicosa, Long 28119 (DUKE), T, AY908066, AY908837; Gymnostomum aeruginosum, Zander 4218 (BUFF), N, AY908050, AY908847; Gyroweisia tenuis, Long 16061 (DUKE), N, AY908062, AY908834; Hamatocaulis vernicosus, Schofield \& al. 99535 (MO), N, AY908251, AY908434; Hampeella pallens, Streimann 44664 (NY), S, AY306921, AY452360; Handeliobryum sikkimense, Redfearn \& al. 33980 (MO), T, AY908267, AY908672; Haplocladium virginianum, Buck 32482 (NY), N, AF143040, AY908401; Haplohymenium triste, Goffinet 6484 (DUKE), N, AY908202, AY908458; Hedwigidium integrifolium, Price \& al. 1527 (MO), T, AY907993, AY908379; Helicodontium capillare, Buck 29550 (NY), T, AF143043, AY908516; Helodium blandowii, Shevock 18635 (MO), N, AY908339, AY908393; Hemiragis aurea, Dauphin 2949 (NY), T, AY306922, AY452361; Herpetineuron toccae, Buck 39973 (NY), N, AY908566, AY908638; Herzogiella adscendens, Schofield 108033 (MO), N, AY908557, AY908404; Heterocladium dimorphum, Shevock 19252 (MO), N, AY908259, AY908640; Heterophyllium affine, Buck 21676 (NY), N, AY908577, AY908466; Hildebrandtiella endotrichelloides, Magill \& Pocs 11732 (MO), T, AY306925, AY908702; Himantocladium cyclophyllum, Jordan s.n. (UCONN), T, AY908268, AY908472; Holomitriopsis laevifolia, Leisner 23093 (DUKE), T, AY908135, AY908915; Holomitrium arboreum, Churchill \& al. 20417 (MO), T, AY908109, AY908881; Homalia trichomanoides, Schofield 96279 (MO), N, AY908276, AY908673; Homaliadelphus targionianus, Allen 6752 (MO), N, AY908552, AY908449; Homaliodendron flabellatum, Allen 12674 (MO), T, AY908271, AY908671; Homalotheciella subcapillata, Buck 332517 (NY), N, AF143061, AY908510; Homalothecium sericeum, Magill 10071 (MO), N, AY908313, AY908521; Homomallium adnatum, Allen 22258 (MO), N, AY908554, AY908387; Hookeriopsis cuspidata, Allen 19061 (MO), T, AY908608, AY908456; Horikawaea redfearnii, Tan \& Gruezo 92-379 (NY), T, AY908600, AY908704; Horridohypnum mexicanum, Delgadillo 6149 (MO), T, AY908349, AY908630; Hydropogon fontinaloides, Allen Font.exs. \# 54 (DUKE), T, AY908216, AY908535; Hygroamblystegium varium, Buck 32563 (NY), N, AY908247, AY908429; Hygrodicranum boliviana, Buck 39497 (DUKE), T, AY908115, AY908904; Hygrohypnum smithii, Goffinet 7968 (UCONN), N, AY908620, AY908985; Hylocomiastrum pyrenaicum, Schofield 101919 (MO), N, AY908181, AY908644; Hylocomiopsis cylindricarpa, Pocs 6177 (NY), T, AY908342, AY908394; Hylocomium splendens, Schofield 98369 (DUKE), N, AY908280, AY908447; Hymenodon pilifer, Streimann 58994 (MO), S, AY908176, AY908778; Hymenostylium recurvirostre, Bachmann 538 (DUKE), N, AY908121, AY908859; Hyocomium armoricum, Schwartz 2049 (MO), N, AY907955, AY908533; Hyophiladelphus agrarius, Bowers \& LeLong 15446 (DUKE), N, AY908067, AY908838; Hypnella diversifolia, Buck 39277 (NY), T, AY306931, AY452364; Hypnobartlettia fontana, Frahm 1998 (MO), S, AY908245, AY908428; Hypnodendron microstictum, Crosby 16261 (DUKE), S, AY908008, AY908771; Hypnodontopsis spathulatus, Murata \& al. 22245 (CONN), T, AY908119, AY908964; Hypnum cupressiforme, Cox 599 (DUKE), N, AF469845, AY908444; Hypodontium dregei, Arts 105/05 (DUKE), S, AY908112, AY908877; Hypopterygium tamarisci, Buck 35314 (NY), T, AY449666, AY452367; Indusiella thianshanica, Long 26986 (DUKE), N, AY908139, AY908923; Ischyrodon leptura, Streimann 54790 (MO), S, AY908591, AY908755; Isocladiella surcularis, Schäfer-Verwimp \& Verwimp 21005 (NY), T, AY908204, AY908467; Isodrepanium lentulum, Allen 23460 (MO), T, AY907964, AY908530; Isopterygiopsis muelleriana, Buck 25170 (NY), N, AY908322, AY908764; Isopterygium tenerum, Buck 33462 (NY), N, AF143037, AY908546; Isothecium myosuroides, Schofield 105739 (NY), N, AY306933, AY908661; Iwatsukiella leucotricha, Schofield 98995 (MO), N, AY908583, AY908740; Jaegerina scariosa, Goffinet 6144 (herb. Goffinet), T, AY908601, AY908462; Jaffueliobryum latifolium, Long 23992 (DUKE), T, AY908617, AY908950; Jonesiobryum cerradense, Yano 4677 (NY), T, AY908120, AY908901; Juratzkaeella sinensis, Magill 7662 (MO), T, AY908198, AY908751; Kiaeria gracilis, Long 30073 (E), N, AY908085, AY908900; Leiomela bartramioides, Goffinet 6428 (herb. Goffinet), T, AY907991, AY908969; Leiomitrium plicatum, Arts (1120:nad5) (1121:rps4) (herb. Goffinet), T, AY908003, AY908939; Lembophyllum divulsum, Streimann 58549 (MO), S, AY306935, AY908656; Lepidopilidium portoricense, Buck 37825 (NY), T, AY306939, AY452369; Lepidopilum scabrisetum, Buck 39436 (NY), T, AY306940, AY452370; Leptobarbula berica, Long 15819 (DUKE), N, AY908063, AY908835; Leptodictyum riparium, Parfitt 5903 (MO), N, AY907967, AY908713; Leptodon smithii, Rumsey s.n. (herb. Rumsey), N, AY908261, AY908641; Leptodontiopsis fragilifolia, Pocs 9225/AZ (herb. Goffinet), T, AY908170, AY908947; Leptodontium luteum, Churchill 19048 (BUFF), T, AY908045, AY908841; Leptohymenium tenue, Redfearn, He \& Su 799a (NY), T, AY908581, AY908389; Leptopterigynandrum austro-alpinum, Churchill \& al. 19933 (MO), T, AY908190, AY908744; Leptostomum inclinans, Streimann 47937 (DUKE), S, AY907974, AY908359; Leptotheca gaudichaudii, Cox \& Goffinet 459/00 (DUKE), S, AY907994, AY908781; Leptotheca boliviana, Cox 58/01 (DUKE), T, AY908177, AY908779; Lescuraea radicosa, Whittemore 5372 (NY), N, AY908326, AY908737; Leskeadelphus bolivianus, Churchill 17611 (MO), T, AY907948, AY908411; Leskeella nervosa, Allen 21504 A (NY), N, AY908325, AY908414; Leskeodon auratus, Buck 18286 (NY), T, AY306942, AY452371; Leucobryum crispum, Buck 39451 (DUKE), T, AY908134, AY908914; Leucoloma sprengelianum, Arts RSA 104/09 (DUKE), S, AY908110, AY908889; Leucomium strumosum, Holz FG 00-268 (NY), T, AY306943, AY908488; Levierella fabroniacea, Magill 10833 (MO), T, AY907961, AY908528; Limbella tricosta, Schofield \& Belland 88077 (DUKE), T, AY908572, AY908441; Lindbergia brachyptera, Allen 10907 (MO), N, AY907949, AY908412; Lindigia aciculata, Churchill \& al. 16292 (DUKE), T, AY908304, AY908512; Loeskeobryum brevirostre, Buck 32522 (NY), N, AY908278, AY908635; Loeskypnum badium, Schofield 111164 (MO), N, AY907969, AY908712; Lorentziella imbricata, Schinini 24785 (NY), S, AF223052, AY908973; Luisierella barbula, Nash 313 (herb. Goffinet), T, AY908155, AY908975; Lyellia crispa, Long 22956 (DUKE), T, AY908020, AY908801; Macrocoma tenue, Arts 04/04 (herb. Goffinet), T, AY908004, AY908940; Macrothamnium macrocarpum, Shevock 14459 (MO), T, AY908182, AY908390; Mahua enervis, Slack s.n. (NY), N, AY908319, AY908761; Matteria gracillima, Goffinet 7197a (herb. Goffinet), S, AY907947, AY908621; Meesia triquetra, Schofield 99251A (DUKE), N, AY499647, AY908977; Meiothecium chlorocladum, Heras 286/94 (NY), T, AY908217, AY908483; Meiotrichum lyellii, Norris 78644 (NY), N, AY908012, AY908802; Mesonodon flavescens, Kolema 13220 (NY), T, AY908255, AY908529; Mesotus celatus, Streimann 58236 (NY), S, AY908105, AY908888; Metaneckera menziesii, Schofield 105417 (DUKE), N, AY908264, AY908648; Meteoridium remotifolium, Allen 20563 (MO), T, AY306949, AY908517; Meteoriella soluta, Shevock 14337 (MO), T, AY306950, AY908637; Meteoriopsis reclinata, Shevock 17996 (MO), T, AY908283, AY908726; Microbryum dallavianum, Eckel \& Zander 9104014 (NY), N, AY908033, AY908825; Microcampylopus leucogaster, Lyon 137A (MO), T, AY908136, AY908908; Micromitrium austinii, Buck 24917 (DUKE), T, AY908093, AY908917; Mielichhoferia elongata, Shaw s.n. (RNG), N, AF023793, AY312878; Mittenothamnium reptans, Allen 18674 (MO), T, AY908346, AY908627; Mitthyridium constrictum, Withey 560 (DUKE, T, AF306987, AY908976; Mniomalia semilimbata, Hoffmann 89685 (NY), T, AY907986, AY908373; Mnium hornum, Cox 115 (RNG), N, AF023796, AY312879; Molendoa sendtneriana, Dall'Aglio 428 (BUFF), T, AY908053, AY908846; Muellerobryum whiteleggei, Newton \& Bell 5462 (herb. Newton), T, AY908602, AY908688; Myurella tenerrima, Schofield \& al. 97975 (DUKE), N, AF469822, AY908758; Myurium hockstetteri, Rumsey 17/7 (herb. Rumsey), N, AY908180, AY908439; Myuroclada maximoviczii, Shevock 16232 (MO), N, AY908309, AY908526; Neckera pennata, Anderson 26335 (DUKE), N, AY908265, AY908652; Neckeropsis disticha, Buck 33041 (NY), T, AF143010, AY908675; Neobarbella comes, Yung-ge 3417 (MO), T, AY306954, AY908664; Neodicladiella pendula, Shevock 18116 (MO), T, AY908284, AY908727; Neodolichomitra yunnanensis, Shevock 17903 (MO), T, AY908297, AY908506; Neolindbergia cladomnioides, Akiyama 24232 (NY), T, AY908194, AY908442; Neomeesia paludella, Goffinet 5862 (herb. Goffinet), S, AF306993, AY908984; Neorutenbergia usagarae, Pocs \& al. 88110/A (NY), T, AF143019, AY908631; Noguchiodendron sphaerocarpum, Akiyama Th-112 (HYO), T, AY907958, AY908464; Notoligotrichum australe, Streimann 51321 (MO), S, AY908017, AY908803; Ochrobryum gardneri, Allen 13706 (MO), T, AY908138, AY908916; Oedicladium doii, Glime 4502 23 (NY), T, AY908592, AY908738; Oedipodium griffithianum, Schofield 98670 (DUKE), N, AF306968, AY312880; Okamuraea hakoniensis, Yamaguchi 162 (MO), N, AY908311, AY908496; Oligotrichum parallelum, Schofield 108955 (MO), N, AY908014, AY908805; Oncophorus wahlenbergii, Schofield 112320 (DUKE), N, AY908083, AY908891; Oreas martiana, Long 20863 (DUKE), T, AY908084, AY908892; Oreoweisia laxifolia, Shevock 19097 (MO), T, AY908080, AY908898; Orthodicranum flagellare, Churchill 19600 (NY), N, AY908108, AY908882; Orthodontium lineare, Hedderson s.n. (RNG), N, AF023800, AY312881; Orthodontopsis bardunowii, Ignatov s.n. (DUKE), N, AY908178, AY908780; Orthomitrium tuberculatum, Crosby 16040 (MO), N, AY908172, AY908785; Orthorrhynchium elegans, Streimann 53758 (NY), T, AY908612, AY908766; Orthostichella pentasticha, Cardenas 5891 (MO), T, AY907962, AY908655; Orthostichidium involutifolium, Magill \& Crosby 8387 (MO), T, AY908195, AY908700; Orthotheciella varia, Shevock 15238 


\section{Appendix 2 (continued).}

Taxon, Collector, Collection number and (voucher location), Latitudinal region, rps4, nad5

(NY), N, AY908238, AY908430; Orthothecium chryseum, Schofield 102114 (MO), N, AY907966, AY908759; Orthotrichum anomalum, Vitt Orth. exs. 43 (DUKE), N, AF306970, AY908979; Oxyrrhynchium rugosipes, Withey 534 (DUKE), T, AY908315, AY908514; Palamocladium leskeoides, Churchill 20419 (DUKE), T, AY908296, AY908499; Palisadula chrysophylla, Buck 9620 (NY), N, AY908593, AY908739; Palustriella commutata, Shevock 18521 (MO), N, AY908243, AY908421; Papillidiopsis complanata, Tan 95-1011 (NY), T, AY908220, AY908482; Paraleucobryum enerve, Long 16815 (DUKE), T, AY908106, AY908883; Paranapiacabaea paulista, Vital \& Buck 20614 (NY), T, AY908218, AY908480; Pentastichella pentastichum, Goffinet 5489 (UCONN), S, AY908167, AY908783; Penzigiella cordata, Weber B-99381 (NY), S, AY306972, AY908653; Philonotis fontana, Cox 117 (RNG), N, AF023801, AY908384; Philophyllum tenuifolium, Schäfer-Verwimp 14548 (NY), T, AY306973, AY452376; Phyllodon truncatulus, Buck 33300 (NY), T, AY908604, AY908682; Phyllodrepanium falcifolium, Buck 3001 (DUKE), T, AF143074, AY908374; Physcomitrella patens, Whitehouse s.n. (UC), N, AY908158, AY908932; Physcomitrium lorentzii, Goffinet 5348 (DUKE), S, AF223046, AY908933; Pilopogon gracilis, Breedlove 66830 (MO), T, AY908137, AY908907; Pilosium chlorophyllum, Buck 32979 (NY), T, AF143059, AY908749; Pilotrichidium callicostatum, Betancur \& al. 4725 (NY), T, AY306977, AY908455; Pilotrichopsis dentata, Buck 23843 (NY), N, AY908599, AY908715; Pilotrichum bipinnatum, Holz 00-33 (NY), T, AY306976, AY452378; Pinnatella piniformis, Allen 23700 (DUKE), T, AY907963, AY908654; Pireella angustifolia, Goffinet 2889 (DUKE), T, AY908565, AY908692; Plagiobryum zierii, Schofield 106269 (MO), N, AY907973, AY908355; Plagiomnium cuspidatum, Schwab s.n. (DUKE), N, AY907978, AY908365; Plagiopus oederi, Goffinet 3522 (ALTA), N, AY907990, Z98962; Plagiothecium cavifolium, Buck 32520 (NYBG), N, AY908321, AY908763; Platygyriella aurea, Long 16425 (DUKE), T, AY908575, AY908622; Platygyrium repens, Buck 33448 (NY), N, AY908234, AY908623; Platyhypnidium riparioides, Allen 22317 (MO), N, AY908298, AY908504; Platylomella lescurii, Allen 22294 (MO), N, AY908337, AY908402; Platyneuron laticostatum, Goffinet 8405 (herb. Goffinet), S, AY908613, AY908960; Pleuridium subulatum, Anderson 27634 (DUKE), N, AF306980, AY908952; Pleurochaete squarrosa, Goffinet 6453, T, AY908058, AY908854; Pleurophascum grandiglobum, Streimann 51183 (NY), S, AY908101, AY908961; Pleurorthotrichum chilense, Goffinet 5320 (herb. Goffinet), S, AY908168, AY908784; Pleuroziopsis ruthenica, Schofield 111104 (DUKE), N, AY908571, AY908647; Pleurozium schreberi, Thornton 35 (DUKE), N, AY908281, AY908642; Pohlia nutans, Shaw 8586 (DUKE), N, AY907983, AY908369; Polytrichadelphus purpureus, Cox 84/01 (DUKE), T, AY330480, AY312883; Polytrichastrum alpinum, Ledlie 1066 (MO), N, AY908013, AY908807; Polytrichum pallidisetum, Goffinet 4581 (herb. Goffinet), N, AF306956, AY312884; Porothamnium arbusculans, Holz \& Franzaring 00-86 (MO), S, AY908277, AY908679; Porotrichodendron nitidum, Buck 39580 (DUKE), T, AY908273, AY908678; Porotrichopsis flacca, Churchill \& Betancur 17934-C (NY), T, AY908275, AY908676; Potamium lonchophyllum, Churchill \& al 17638 (MO), T, AY908221, AY908540; Pottia truncata, Long 21805 (DUKE), N, AY908122, AY908860; Prionodon densus, Churchill \& al. 19068 (NY), T, AF143076, AY908718; Pseudephemerum nitidum, Soldan s.n. (DUKE), N, AY908074, AY908856; Pseudobraunia californica, Whittmore 3550 (DUKE), N, AY908143, AY908787; Pseudobryum cinclidioides, Hedderson s.n. (RNG), N, AY907980, AY908367; Pseudocalliergon angustifolium, Allen 19684 (MO), N, AY908242, AY908423; Pseudocrossidium aureum, Christy \& Pigg 2173B (MO), N, AY908034, AY908827; Pseudoleskea andina, Buck 39552A (NY), T, AY908257, AY908696; Pseudoleskeella tectorum, Schofield 94788 (MO), N, AY907950, AY908416; Pseudoleskeopsis imbricata, Schofield \& Ramsay 90971 (DUKE), S, AY908582, AY908410; Pseudopterobryum tenuicuspis, Si-Min 256 (MO), N, AY907959, AY908668; Pseudoscleropodium purum, Goffinet 4720 (DUKE), N, AF143030, AY908505; Pseudospiridentopsis horrida, Averyanov B115 (MO), T, AY306981, AY908721; Pseudosymblepharis guatemalensis, Allen 18868 (MO), T, AY908056, AY908850; Pseudotaxiphyllum elegans, Ledlie 262 (MO), N, AY908578, AY908753; Pseudotrachypus martinicensis, Buck 8207 (NY), T, AY306982, AY908729; Pseudotrimegistia undulata, Akivama Th35 (NY), T, AY908618, AY908980; Psilopilum cavifolium, Schofield 108367 (MO), N, AY908015, AY908808; Pterigynandrum filiforme, Schofield \& Belland 92748 (MO), N, AY908189, AY908757; Pterobryella praenitens, Streimann 56079 (NY), S, AF307002, AY908769; Pterobryon densum, Linares \& Churchill 3649 (NY), T, AF143013, AY908693; Pterobryopsis stolonacea, Churchill \& al. 20104 (MO), T, AY908595, AY908701; Pterogonidium pulchellum, Djan-Chekar 94-23 (NY), T, AY908232, AY908487; Pterogoniopsis cylindrica, Zardini 5055 (MO), T, AY908213, AY908537; Pterogonium gracile, Whittemore 6599 (MO), N, AY907970, AY908667; Pterygoneurum ovatum, Shevock 15251 (MO), N, AY908038, AY908818; Ptilium crista-castrensis, Long 28250 (E), N, AY908282, AY908643; Ptychodium plicatum, Paton 2723 (E), N, AY908327, AY908735; Ptychomitrium gardneri, Ireland 7038 (PMAE), N, AY908616, AY908951; Ptychomnion aciculare, Streimann 43623 (NY), S, AY306983, AY452380; Puiggariopsis aurifolia, Buck 35534 (NY), T, AY908348, AY908626; Pulchrinodus inflatus, Streimann 51162 (NY), S, AY907975, AY908360; Pylaisiadelpha tenuirostris, Buck 32500 (NY), N, AF143053, AY908547; Pylaisiella polyantha, Stebel \& Stebel 600/95 (MO), N, AY907960, AY908408; Pylaisiopsis speciosa, Miehe 14071a (NY), T, AY908555, AY908475; Quathlamba debilicostata, Long \& Rae 924 (DUKE), T, AY908159, AY908792; Racomitrium crispipilum, Buck 39718 (DUKE), T, AY908146, AY908922; Radulina borbonica, Heras 515/94 (NY), T, AY908223, AY908485; Regmatodon declinatus, Magill \& al 7689 (MO), T, AY908191, AY908413; Renauldia mexicana, Norris 77310 (DUKE), T, AY908333, AY908666; Rhabdoweisia crispata, Goffinet 4553 (herb. Goffinet), N, AF222899, AY908966; Rhachithecium papillosum, Pocs \& Lye 97123A (herb. Goffinet), T, AF306978, AY908963; Rhacopilopsis trinitensis, Allen 20571 (MO), T, AY908225, AY908543; Rhamphidium dicranoides, Ramirez \& al 8.339-A (MO), T, AY908089, AY908867; Rhaphidostichum schwaneckeanum, Hill 27911 (NY), T, AY908222, AY908484; Rhexophyllum subnigrum, Churchill 19804 (MO), T, AY908035, AY908817; Rhizofabronia persoonii, Magill \& Pocs 11061 (MO), T, AY908607, AY908765; Rhizomnium gracile, Schofield 76795 (DUKE), N, AY907976, AY908362; Rhodobryum giganteum, Longton 5073 (RNG), T, AF023789, AY312886; Rhynchostegiella capillacea, Allen 11414 (MO), T, AY908306, AY908515; Rhynchostegiopsis flexuosa Allen 18710 (NY), T, AY449667, AY452383; Rhynchostegium serrulatum, Buck 33460 (NY), N, AY908301, AY908502; Rhytidiadelphus triquetrus, Thornton 20a (DUKE), N, AY908279, AY908636; Rhytidiopsis robusta, Goffinet 7874 (UCONN), N, AY908574, AY908465; Rhytidium rugosum, Rumsey 1988 (herb. Rumsey), N, AY907951, AY908415; Rigodiadelphus robustus, Deguchi 164 (MO), N, AY908569, AY908736; Roellia roellii, Schofield \& Godfrey 97885 (DUKE), N, AY907981, AY908368; Rosulabryum albolimbatum, Streimann 57424 (NY), T, AY907971, AY908356; Rozea pterogonioides, Long 17566 (DUKE), T, AY907957, AY908544; Rutenbergia madagassa, Magill \& al. 9583 (DUKE), T, AY908605, AY908632; Saelania glaucescens, Hedderson 8339 (NY), N, AY908148, AY908924; Sanionia orthothecioides, Schofield \& Talbot 111743 (MO), N, AY908253, AY908436; Sauloma tenella, Streimann 59726 (NY), S, AY306987, AY452384; Schimperobryum splendidissimum, Holz \& Franzaring Ch 00-156 (NY), S, AY306988, AY452385 Schistidium apocarpum, Schofield \& Talbot 10363 (DUKE), N, AY908145, AY908920; Schistomitrium breviapiculatum, Koponen 35844 (NY), T, AY908133, AY908913; Schlotheimia torquata, Allen 11979 (MO), T, AY908005, AY908935; Schoenobryum concavifolium, Zardini \& al. 40631 (MO), T, AY908580, AY908697; Schofieldiella micans, Buck 37073 (NY), N, AY908235, AY908624; Schroeterella zygodonta, Buck 39478 (NY), T, AY908209, AY908478; Schwetschkea grateloupii, Magill \& Pocs 11670a (MO), T, AY908305, AY908509; Schwetschkeopsis fabronia, Buck 33461 (NY), N, AF143041, AY908743; Sclerodontium pallidum, Streimann 61222 (MO), S, AY908111, AY908890; Scleropodium obtusifolium, Shevock \& York 17142 (MO), N, AY306989, AY908525; Scorpidium scorpioides, Shaw 9718 (DUKE), N, AY908584, AY908435; Scorpiurium deflexifolium, Bab Taza del Jbel Bouhalla s.n. (NY), N, AY908300, AY908507; Sehnemobryum paraguense, Vitt 21097 (ALTA), T, AY908174, AY908936; Sematophyllum demissum, Buck 24259 (NY), N, AY908214, AY908479; Serpotortella chenagonii, Orban 9424/CA (MO), T, AY908113, AY908878; Sphaerotheciella sphaerocarpa, Long 30637-a (DUKE), T, AY908589, AY908698; Sphagnum palustre, Long 28667 (DUKE), T, AF231892, AY312888; Spiridens reinwardtii, Withey 908 (DUKE), T, AY908009, AY908772; Spiridentopsis longissima, Schafer-Verwimp 13185 (MO), T, AY908564, AY908690; Splachnobryum obtusum, Buck 29822 (NY), T, AF223058, AY908855; Squamidium brasiliense, Churchill \& Schiavone 19995 (MO), T, AY908316, AY908518; Steerecleus serrulatus, Anderson 27826 (DUKE), N, AY908302, AY908500; Stegonia latifolia, LaFarge 10-08-90 (ALTA), N, AY908039, AY908826; Stenocarpidiopsis saliciola, Buck 39543 (NY), T, AY908307, AY908508; Stenodesmus tenuicuspis, Ramirez 8.328 (MO), T, AY908610, AY908453; Stenodictyon wrightii, Buck 10014 (NY), T, AY306998, AY452386; Stereophyllum radiculosum, Zardini 7102 (DUKE), T, AF469846, AY908750; Stoneobrvum mirum, Vanderpoorten 156 (Herb. Goffinet), S, AY908551, AY908981; Streptocalypta tortelloides, Breedlove \& Bourel 67446 (MO), T, AY908055, AY908839; Streptopogon calymperes, Price1733 (MO), T, AY908044, AY908813; Struckia argentata, Long 2001 (DUKE), T, AY908320, AY908762; Symblepharis lindigii, Price 1467 (MO), T, AY908076, AY908893; Symphyodon imbricatifolius, Schäfer-Verwimp 14747 (NY)., T, AY306999, AY452387; Symphysodon longicuspis, Newton \& Bell 5367 (herb. Newton), T, AY908596, AY908706; Symphysodontella cylindricea, Withey 545 (DUKE), T, AY908597, AY908707; 


\section{Appendix 2 (continued).}

Taxon, Collector, Collection number and (voucher location), Latitudinal region, rps4, nad5

Syrrhopodon texanus, Zartman 1375 (DUKE), N, AY908153, AY908876; Taiwanobryum speciosum, Yamaguchi 86 (MO), N, AY908272, AY908669; Takakia lepidozioides, Schofield 86563 (DUKE), N, AF306950, AY312889; Taxiphyllopsis iwatsukii, Deguchi 28253 (NY), N, AY908351, AY908432; Taxiphyllum diplanatum, Newton, Equihua \& DeLuna 4651 (Pers. Herb.), T, AY908350, AY908742; Tetraphidopsis pusilla, Fife 11592 (NY), S, AY307001, AY452389; Tetraphis pellucida, Risk 105858 (DUKE), N, AY908021, AY908812; Tetraplodon mnioides, Soderstrom s.n. (RNG), N, AF023804, AY908376; Tetrapterum recuvirostrum, Vital \& Buck 12121 (NY), T, AY908059, AY908853; Tetrastichium fontanum, Düll Bryophyta Exs. Madeira 69 (NY), N, AY307000, AY452388; Tetrodontium brownianum, Snider \& He 3202 (DUKE), N, AY908022, AY908809; Thamniopsis pendula, Churchill \& Lineares 18434 (NY), T, AY307003, AY452392; Thamnobryum alopecurum, Cox 147 (RNG), N, AF023834, AJ291571; Thelia lescurii, Buck 32864 (NY), N, AF143024, AY908745; Thuidiopsis furfurosa, Streimann 56057 (NY), S, AY908341, AY908397; Thuidium delicatulum, Buck 32594 (NY), N, AF143039, AY908398; Timmiella anomala, Weber 1978 (BUFF), N, AY908163, AY908958; Toloxis imponderosa, Buck 39522 (DUKE), T, AY908289, AY908732; Tomentypnum falcifolium, Shaw 10186 (DUKE), N, AY908567, AY908431; Tortula subulata, O'Shea s.n. (DUKE), N, AY908040, AY908814, Touwia ellipticum, Akiyama 22448 (NY), T, AY908270, AY908674; Trachybryum megaptilum, Shevock \& Toren 20090 (MO), N, AY908312, AY908522; Trachyphyllum gastrodes, O'Shea M7010a (DUKE), T, AY908236, AY908532; Trachypodopsis serrulata, Pocs 9150/L (MO), T, AY307008, AY908720; Trachyxiphium drepanophyllum, Vital \& Buck 20012 (NY), T, AY307005, AY452394; Trematodon longicollis, He \& Song 00321 (MO), N, AY908087, AY908865; Trichodon cylindricus, Vitt 35814 (NY), N, AY908125, AY908863; Trichosteleum papillosum, Buck 33002 (NY), T, AF143056, AY908541; Trichostomum tenuirostre, Zander \& Eckel 1996 (BUFF), N, AY908057, AY908852; Tridontium tasmanicum, Streimann 51280 (MO), S, AY908048, AY908829; Tripterocladium leucocladium, Schofield \& Belland 91206 (NY), N, AY908334, AY908662; Triquetrella californica, Shevock 18920 (BUFF), N, AY908025, AY908840; Tuerckheimia valeriana, Holz \& Schäfer-Verwimp 99-1178 (MO), T, AY908052, AY908833; Uleastrum paraguensis, Zardini \& Aquino 32310 (DUKE), T, AY908118, AY908965; Ulota phyllantha, Schofield 100736 (DUKE), N, AY908173, AY908941; Venturiella sinensis, Deguchi 1996 (MO), N, AY908117, AY908868; Vesicularia vesicularis, Newton 4552 (herb. Newton), T, AY908559, AY908406; Vittia pachyloma, Goffinet 5605 (DUKE), S, AY908240, AY908463; Warburgiella leucocytus, Shaw 10589 (DUKE), S, AY908219, AY908538; Wardia hygrometrica, Hedderson 11709 (RNG), S, AF023782, AY908880; Warnstorfia exannulatus, Schofield 111496 (NY), N, AY907968, AY908711; Weisiopsis anomala, Shevock 16412 (MO), N, AY908070, AY908864; Weissia controversa, Bovers 15234 (BUFF), N, AY908060, AY908849; Weymouthia mollis, Streimann 58094 (MO), S, AY307013, AY908659; Wijkia extenuata, Streimann 61180 (MO), S, AY908205, AY908542; Wilsoniella karsteniana, Churchill, Gail \& Kantak 12519-B (NY), T, AY908088, AY908866; Zelometeorium patulum, Allen 19462 (MO), T, AY307017, AY908520; Zygodon bartramioides, Goffinet 5476 (DUKE), S, AY908169, AY908978. 